\title{
Holocene foraminiferal and geochemical records in the coastal karst dolines of Cres Island, Croatia
}

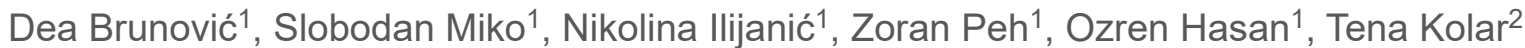 \\ Martina Šparica Miko ${ }^{1}$ and Ivan Razum ${ }^{3}$ \\ ${ }^{1}$ Croatian Geological Survey, Sachsova 2, 10000 Zagreb, Croatia; (dea.brunovic@hgi-cgs.hr) \\ 2 University of Zagreb, Faculty of Mining, Geology and Petroleum Engineering, Pierottijeva 6, 10000 Zagreb, Croatia \\ ${ }^{3}$ Croatian Natural History Museum, Demetrova 1, 10000 Zagreb, Croatia
}

doi: $10.4154 / g c .2019 .02$

Article history:

Manuscript received July 04, 2018

Revised manuscript accepted October 25, 2018

Available online February 15, 2019

\begin{abstract}
Numerous karst dolines have been formed along the Croatian coast and many have been submerged during the Late Glacial and Holocene sea level rise. The coastal area of Cres Island in the Northern Adriatic is a typical example of this geomorphological setting, where transitional forms from subaerial to submerged dolines are present. Once dolines are formed they can accumulate soil, water and sediments due to their morphology. Sediments are an especially valuable source of environmental data. This paper presents the results of the study of foraminiferal assemblages and sediment geochemistry, supplemented with grain-size and mineralogical data, from the marine ponds developed in the karst dolines on Cres Island. Obtained data is correlated with the sediment core record from submerged dolines in the present-day embayments along the coastal zone of Cres Island. In total, 3 sediment cores were collected in the marine ponds Marinska, Arcij and Podbrajde, while 2 longer sediment cores have been extracted from the Jaz and Sonte embayments. The Marinska, Arcij and Podbrajde marine ponds have distinct geochemical and mineralogical sediment compositions, with monospecific foraminiferal assemblages and generally differ from each other. The common characteristics are their high $\mathrm{N}$ and $\mathrm{P}$ concentrations and the algal origin of organic matter. Agglutinated foraminiferal taxa (Haplophragmoides canariensis and Trochammina inflata), typical for intertidal environments, are abundant in the brackish-water Marinska pond, while stress-tolerant species Ammonia tepida has been identified in the Arcij marine pond. Environmental conditions in the Podbrajde marine pond did not facilitate the development of a rich foraminiferal fauna. Results from the present-day marine ponds enabled recognition of similar environments in the sediment cores collected in the Jaz and Sonte embayments that were progressively inundated during the Holocene sea level rise. A palaeo-marine pond existed in the Sonte embayment until 6610 cal BP, when the sea flooded the investigated area. A marine pond in the Jaz embayment was formed at $711 \mathrm{cal}$ BP. Low-diversity foraminiferal assemblages in these palaeo-ponds are similar to those recognized in the present-day Arcij marine pond on Cres Island. However, differences in the geochemical composition of palaeo-marine ponds, in comparison to the present-day ponds, exist. They might be attributed to climate variability over time and variations in the geological setting of each environment. High Mo concentrations and abundant organic matter content are the main sediment characteristics of the recognized palaeo-marine ponds in the Jaz and Sonte embayments.
\end{abstract}

Keywords: karst dolines, sediment cores, Holocene, marginal marine environments, sea level change, foraminifera, organic carbon, trace elements, Adriatic Sea dolines with surface connection to the sea. In the literature, this type of environment is termed a marine lake (JURAČIĆ et al., 1995; GOVORČIN et al., 2001; VANIČEK et al., 2000; SURIĆ, 2002; SURIĆ, 2005; SONDI \& JURAČIĆ, 2010; PIKELJ \& JURAČIĆ, 2013). Marine lakes can also be found on other parts of the eastern Adriatic coast, such as Zmajevo oko near Rogoznica and Mir on Dugi otok Island. These shallow water environments have a subsurface connection to the sea allowing seepage through karstified bedrock (SURIĆ, 2002; SURIĆ, 2005; PIKELJ \& JURAČIĆ, 2013). Since marine lakes are located in the coastal karst zone and the marine influence on their development is substantial, these environments can be considered as marginal marine types and they can preserve a record of the Holocene sea level rise (WUNSAM et al., 1999; GOVORČIN et al., 2001). Other types of marginal marine environments (lagoons, estuaries and salt-marshes) have also been developed along the Croatian coastline (PANDŽA et al., 2007; PIKELJ \& JURAČIĆ, 2013). However, considerable work has yet to be conducted in terms of the description and characterization of the different types of tranMalo Jezero on Mljet Island are examples of submerged karst 
sitional environments present along the karstified eastern Adriatic coast.

The focus of many foraminiferal studies worldwide is the determination of species and their dependence on sea level and other environmental conditions in the salt-marshes (e.g., GEHRELS, 1994; HAYWARD et al., 1999; EDWARDS et al., 2004; SERANDREI BARBERO et al., 2004; KEMP et al., 2013; STÉPHAN et al., 2014; MILKER et al., 2015; MÜLLER-NAVARA et al., 2017), estuaries and coastal lagoons (e.g., SERANDREI BARBERO et al., 1999; DEBENAY et al., 2001; DEBENAY \& GUILLOU, 2002; TAKATA et al., 2006; JAYALAKSHMY \& RAO, 2006; FRONTALINI et al., 2011a; FRONTALINI et al., 2011b; FRONTALINI et al., 2013) and brackish-water coastal lakes (e.g., CARBONI et al., 2009). Evidence for the survival of these typically marine organisms in inland saline lakes and freshwater lakes has also been postulated (BOLTOVSKOY \& LENA, 1971; CANN \& de DEKKER, 1981). Physical and chemical water properties, sediment type, sediment geochemistry, tides, storms, winds, evaporation and distance from a direct marine influence are some of the main environmental parameters that have a crucial impact on the foraminiferal assemblages in the marginal marine environments (DEBENAY et al., 2001; DEBENAY \& GUILLOU, 2002; FRONTALINI et al., 2011a). In general, it is considered that the fauna in these environments is less diverse and dominated by agglutinated species (DEBENAY \& GUILLOU, 2002).

Recent foraminiferal studies along the eastern Adriatic coast have been mostly restricted to investigation of species distribution (VIDOVIĆ, 2010; ĆOSOVIĆ et al., 2011) and to the possible application of foraminifera as indicators of anthropogenic pollution (VIDOVIĆ et al., 2009; POPADIĆ et al., 2013; VIDOVIĆ et al., 2014). Only a few studies have focused on the determination of fauna inhabiting marginal marine environments and their dependence on environmental conditions, as well as their application in palaeoenvironmental reconstructions. However, foraminiferal assemblages in marine lakes on the Mljet Island have been described in detail (VANIČEK et al., 2000; ĆOSOVIĆ et al., 2016), while SHAW et al. (2016) conducted a study of assemblages present in the Jadrtovac and Blace salt-marshes. Results have produced valuable data about sea level variations in the investigated area and proven the utility of salt-marsh foraminifera in transfer functions. FELJA et al. (2015) determined a foraminiferal fauna in sediment cores from the Mirna River valley in Istria in order to decipher the palaeoenvironmental development of the valley.

The geochemical composition of sediments reveals important environmental data. For example, the $\mathrm{C} / \mathrm{N}$ ratio can be useful in the determination of organic matter provenance (MEYERS, 1994; MEYERS, 2003; LAMB et al., 2006). Nitrogen (N) and phosphorus $(\mathrm{P})$ concentrations coupled with total organic carbon (TOC) content are frequently used as indicators of nutrient availability and primary productivity (MEYERS, 1997; DELANEY, 1998; DI et al., 2015). Application of molybdenium (Mo) as a proxy for redox conditions is also common (PEDERSEN, 1989; CRUSIUS et al., 1996; CALVERT \& PEDERSEN, 1993; ALGEO \& LYONS, 2006; SCHOLZ et al., 2017). Lead (Pb) can be indicative of pollution (LORING, 1978; HELALI et al., 2013) by industries and transport or its origin could be $\mathrm{Pb}$ pellets shot during hunting practices in marsh environments (BIANCHI et al., 2011; MIGANI et al., 2015; BORGHESI, 2016).

Examples of the previously conducted research of sediment geochemistry in the marginal marine environments along the Croatian coast of the Adriatic Sea include studies of the Veliko and Malo Jezero (CUCULIĆ et al., 2009; SONDI et al., 2017), Mir (MLAKAR et al., 2015) and Zmajevo oko (MIHELČIĆ et al., 1996) marine lakes. Furthermore, the geochemical composition of sediments from the shallow marine environments in Bakar Bay (CUKROV et al., 2014) and Makirina Cove (ŠPARICA at al., 2005; MIKO et al., 2008; KOMAR et al., 2015) was studied extensively. Most of these studies focused on deciphering natural and anthropogenic metal enrichment and geochemistry was not used in order to reconstruct palaeoenvironments.

Our study offers a new insight into foraminiferal assemblages and sediment geochemistry in the marine ponds along the coastline of Cres Island. These environments have been formed in the karst dolines and should be considered as marginal marine environments due to their proximity to the sea and marine influence through karst. The main aim was to document typical foraminiferal species and their distribution in these unique water bodies since such studies are lacking along the eastern Adriatic coast. Special emphasis was on the determination of the linkages between foraminiferal assemblages and established environmental conditions manifested in the physical and chemical water properties and geochemical, mineralogical and sedimentological properties of the sediment. A further aim was to characterize environments in the Jaz and Sonte embayments, similar to those in the present-day marine ponds on Cres Island, using extracted sediment cores. Obtained results would be indicative of the timing of the existence of Holocene palaeo-marine ponds in these presently submerged karst dolines. We hypothesize that presentday marine ponds on Cres Island represent modern analogs of submerged Holocene palaeo-marine ponds in the Jaz and Sonte embayments.

\section{STUDY AREA}

The investigated environments are located along the southwestern coastline of Cres Island, in the northern part of the Adriatic Sea in the Kvarner region (Fig. 1). This region is characterized by NW-SE elongated islands (Cres, Lošinj, Krk, Rab, Pag), with bays and channels (Rijeka Bay, Kvarnerić Bay, Kvarner Bay, Vinodol-Velebit Channel, Lošinj Channel) located between the Vinodol-Velebit coastline and the Istrian peninsula. Final formation of the steep and rocky eastern Adriatic coast occurred during the Late Glacial and Holocene periods when sea flooded preexisting folded, faulted and karstified relief. Anticlines became island chains while synclines became bays and channels (BENAC \& JURAČIĆ, 1998; JURAČIĆ et al., 1999; KELLETAT, 2005; PIKELJ \& JURAČIĆ, 2013).

The Mesozoic carbonate rocks and their geological setting on Cres Island have been a target of many detailed studies (MAMUŽIĆ, 1968; MAGAŠ, 1968; HUSINEC et al., 2000; KORBAR et al., 2001; KORBAR \& HUSINEC, 2003; FUČEK et al., 2012; FUČEK et al., 2014). Limestones and dolomites of Cretaceous age are predominant sedimentary rock formations. The oldest deposits have been formed during the Lower Cretaceous. Younger Palaeogene strata (foraminiferal limestones and flysch) are sporadically present in the northern part of Cres Island (FUČEK et al., 2014). Quaternary sediments are rather scarce and present in the form of terra rossa outcrops, alluvial deposits and colluvial deposits on the slopes (MAGAŠ, 1968; BENAC \& DURN, 1997).

Subaerial exposure of Cretaceous deposits enabled the formation of numerous karst dolines on Cres Island, especially in its southwestern part. Dolines are enclosed karst depressions with variable depth and dimensions (FORD \& WILLIAMS, 1989). It 

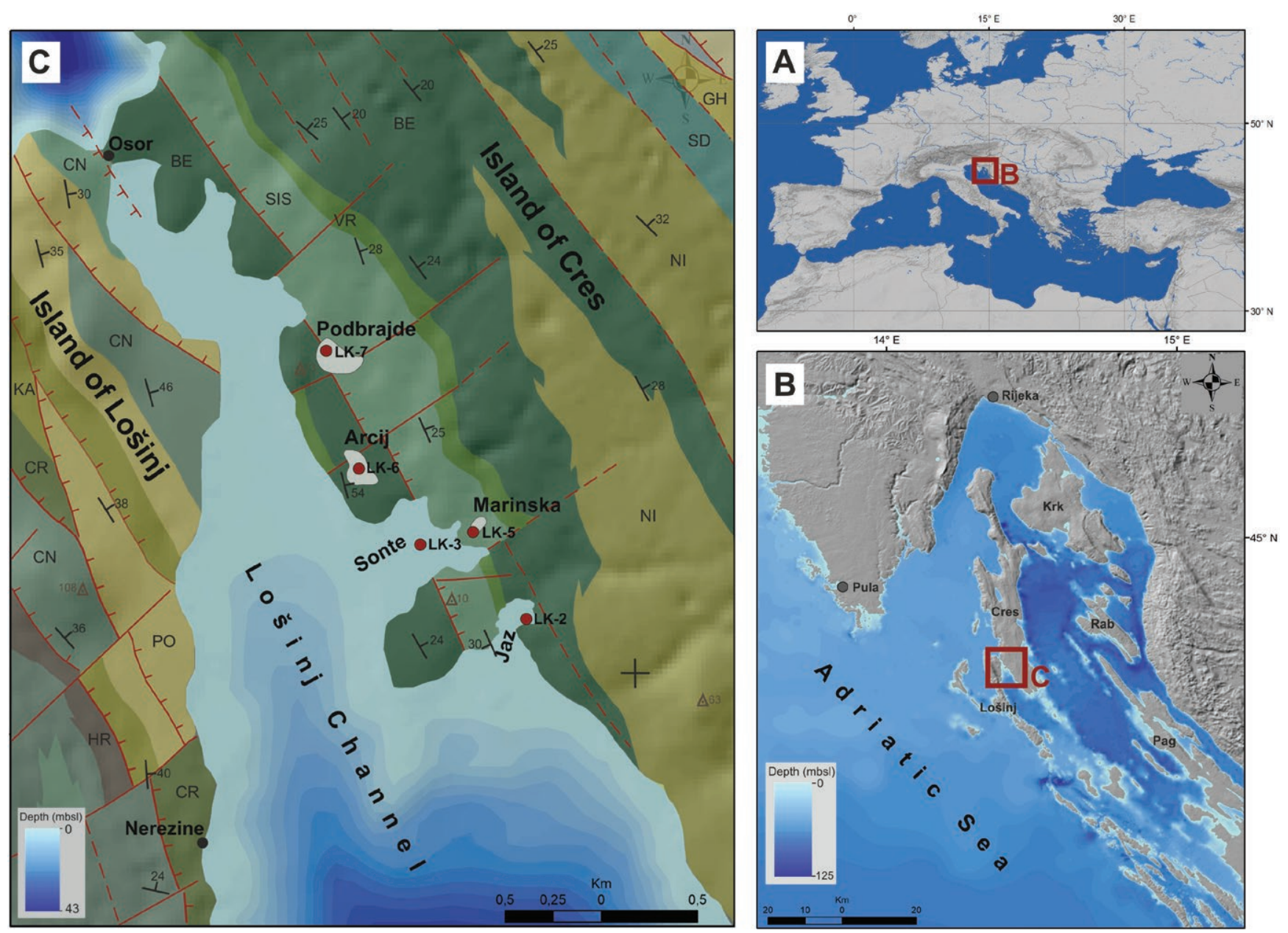

Figure 1. Map of the investigated area. A) Overview, B) Kvarner region and Istrian peninsula, C) Geological map of Cres Island and Lošinj Island (modified from FUČEK et al., 2014) and a bathymetry map of the Lošinj Channel with core locations. Lithostratigraphic units shown on the map: CR-Upper Hauterivian to Barremian Cres limestones, dolomites, stromatolites, breccias and emerged surface alterations; KA- Aptian Kanfanar limestones; PO- Upper Aptian- Lower Albian Porozina breccia and limestones; CN- Albian Crna limestones with emersion breccias; HR- Upper Albian Hrasta dolomites; SIS- Upper Albian-Lower Cenomanian alteration of Sis dolomites and limestones with relict stromatolites, breccia and bauxite infillings; VR-Lower Cenomanian Vrana limestones; BE- Lower to Middle Cenomanian Belej pelagic limestones; NI- Cenomanian Niska limestones; SD- Upper Cenomanian to Turonian Sveti Duh pelagic limestones; GH-Turonian to Coniacian Gornji Humac limestones (FUČEK et al., 2014).

is considered that post-Miocene karstification in the Mediterranean occurred in tectonically susceptible areas during periods of sea level lowstands. The most prominent and best preserved evidence of karstification developed during the most recent sea level lowstand (SURIĆ, 2005; MOCOCHAIN et al., 2009; PIKELJ \& JURAČIĆ, 2013).

The Marinska, Arcij and Podbrajde marine ponds investigated in this study have variable depths, sill elevations separating the pond from the direct marine influence, distances to the sea and size (Tab. 1). They have been developed in the karst dolines within two lithostratigraphic units (Fig. 1), which are composed of alternations of dolomites and shallow marine limestones assigned to the Upper Albian-Lower Cenomanian boundary (Sis unit) and Cenomanian pelagic limestones (Belej unit) (FUČEK et al., 2014). The karstic nature of Cres Island enables sea-water seepage through the karstified sill separating the ponds from the sea. Dip directions trend towards the northeast (FUČEK et al., 2014) which possibly additionally facilitates this seepage through developed layering, underground fissures and conduits.

The study area is microtidal, as recorded on the nearby tide gauge on Lošinj Island (http://tides.mobilegeographics.com/locations/3554.html).

The present-day climate on Cres Island is considered to be temperate and humid with hot summers, while at the highest elevations summers are warm (ŠEGOTA \& FILIPČIĆ, 2003). Meteorological measurements between 1971-2000 at the nearby me-

Table 1. Main characteristics of the investigated environments and collected sediment cores.

\begin{tabular}{|c|c|c|c|c|c|c|c|}
\hline Core location & Environment & Core & Core length $(\mathrm{cm})$ & $\begin{array}{l}\text { Depth at the coring } \\
\text { location }(m)\end{array}$ & $\begin{array}{l}\text { The lowest sill } \\
\text { elevation (m) }\end{array}$ & $\begin{array}{l}\text { Distance to the sea } \\
(\mathrm{m})\end{array}$ & Area $\left(\mathrm{km}^{2}\right)$ \\
\hline Jaz & embayment & LK-2 & 150 & 0.29 & -0.5 & - & 0.029 \\
\hline Sonte & embayment & LK-3 & 371 & 5 & -3 & - & 0.23 \\
\hline Marinska & marine pond & LK-5 & 35.5 & 0.15 & 1.1 & 50 & 0.005 \\
\hline Arcij & marine pond & LK-6 & 46.5 & 0.3 & 0.3 & 92 & 0.018 \\
\hline Podbrajde & marine pond & LK-7 & 34 & 0.15 & 0.7 & 136 & 0.03 \\
\hline
\end{tabular}


teorological station in Mali Lošinj on the Lošinj Island indicate a mean summer air temperature of $23.1^{\circ} \mathrm{C}$, with a maximum of $37.4^{\circ} \mathrm{C}$ occurring in August. During the winter, the temperature decreases significantly and mean air temperature reaches $8.3^{\circ} \mathrm{C}$. The lowest measured air temperature in Mali Lošinj was $-4.4^{\circ} \mathrm{C}$ (ZANINOVIĆ, 2008). Relatively high amounts of rainfall have been recorded in the area, with mean annual precipitation of approximately $930.5 \mathrm{~mm}$ and the highest precipitation rates in the autumn (GAJIĆ-ČAPKA et al., 2008).

The human presence on Cres Island is documented by numerous archaeological sites (REGAN \& NADILO, 2010; DONEUS et al., 2017). The channel that separates islands of Cres and Lošinj in the Osor village has been dug artificially and today has a strong impact on water circulation in the Lošinj Channel, with currents causing deepening of the area south of Osor (DONEUS et al., 2017).

\section{MATERIALS AND METHODS}

Short sediment cores (up to $45.5 \mathrm{~cm}$ long) were collected in the Marinska, Arcij and Podbrajde shallow marine ponds, by inserting a plastic pipe by hand into the sediment. Sampling was conducted in September 2015. In total, 3 cores were extracted (LK-5, LK-6 and LK-7) and subsampled in $1 \mathrm{~cm}$ sections in the field using the core extruder (Tab. 1). Longer sediment cores (up to 371 $\mathrm{cm}$ long) from the Jaz and Sonte embayments were collected using a piston corer and coring platform in April 2014 (Tab. 1). Detailed subsampling of piston cores LK-2 and LK-3 was conducted after splitting the cores lengthwise. Additionally, physical and chemical water parameters such as conductivity, temperature, $\mathrm{pH}$ and dissolved oxygen content were determined at each coring location using a portable multiparameter Multi $3430 \mathrm{WTW}$ probe.

Five mollusc samples from sediment cores LK-2 and LK-3 were dated by radiocarbon dating method $\left(\mathrm{AMS}{ }^{14} \mathrm{C}\right)$ in order to establish core chronology and to determine the timing of palaeoenvironmental changes in the present-day Jaz and Sonte embayments. Analyses have been conducted at Beta Analytics Laboratory in USA. The radiocarbon data was corrected for the marine reservoir effect determined for the Adriatic Sea (FAIVRE et al., 2015).

Grain-size was measured using a laser diffractometer Shimadzu SALD-2300. Selected samples were treated with 30\% hydrogen peroxide $\left(\mathrm{H}_{2} \mathrm{O}_{2}\right)$ in order to remove organic matter. Afterwards, samples were centrifuged, decanted and resuspended in distilled water prior to the analysis. In total, grain-size was determined on 6 samples from sediment cores LK-5 and LK-7, 4 samples from core LK-6, while 25 and 73 samples were analysed from sediment cores LK-2 and LK-3, respectively. Statistical analysis of the grain-size results was conducted using the GRADISTAT software (BLOTT \& PYE, 2001) and sediments were classified according to FOLK \& WARD (1957).

The bulk mineralogical composition of selected samples, as well as their clay mineralogy, was determined using a PANalytical X'Pert Powder X-ray diffractometer. For the measurements, the diffractometer was set at $45 \mathrm{kV}$ and $40 \mathrm{~mA}$, with a step size of $0.02^{\circ} 2 \Theta$. Different phases present in the samples were identified following MOORE \& REYNOLDS (1997). The clay fraction was analysed by mounting oriented aggregates on glass slides, after the removal of carbonates (where needed), using a buffered sodium acetate $(\mathrm{NaOAc})$ solution. Oriented samples were scanned, air-dried, ethylene-glycolated and analysed after being heated to $400^{\circ} \mathrm{C}$ and $550^{\circ} \mathrm{C}$.
Core tops ( $1 \mathrm{~cm}$ thick) of the short sediment cores from marine ponds (LK-5, LK-6 and LK-7) were used for micropalaeontological analysis. Samples were treated with rose Bengal stain and $70 \%$ ethanol in the field and left for 14 days before being washed, following the procedure described by the FOBIMO group (SCHÖNFELD et al., 2012). Piston cores LK-2 and LK-3 from the Jaz and Sonte embayments were analysed in more detail. Foraminiferal analysis on these cores focused on the first $\mathrm{cm}$ of each core and intervals where geochemical, sedimentological and mineralogical data indicated significant shifts. These samples were not treated with rose Bengal stain.

For determination of the total foraminiferal assemblages (stained+empty tests) selected sediment samples were washed over a $63 \mu \mathrm{m}$ sieve in the laboratory in order to remove silt and clay particles. According to SCHÖNFELD et al. (2012) >63 $\mu \mathrm{m}$ fraction is appropriate for foraminiferal analyses in palaeoenvironmental studies. Each sample was divided by microsplitter and approximately 300 specimens were picked. In the samples where the total number of foraminifera specimens was less than 300 , the whole sample was examined and counted. Genera and species were recognized following the available literature and classifications by CIMERMAN \& LANGER (1991), SGARRELLA \& MONCHARMONT ZEI (1993) and LOEBLICH \& TAPPAN (1987). Calculation of the species richness, Shannon-Wiener index, Fisher $\alpha$ index, Dominance, Evenness and Equitability was conducted using the PAST software (HAMMER et al., 2001). Cluster analysis of the total foraminiferal assemblages was performed using STATISTICA 10 software with Ward's method and Euclidean distances (STATSOFT, 2011). Scanning electron microscope (SEM) images of the common agglutinated and calcareous taxa observed in the samples were obtained using the Jeol 35 CF scanning electron microscope, while the chemical composition of their tests was determined using the energy dispersive spectroscopy (EDS-Oxford X-ACT) and INCA detection unit.

Analyses of the total organic (TOC) and inorganic carbon (TIC) and total nitrogen (N) were performed on 134 samples on a Thermo Fisher Scientific Flash 2000 NC Analyzer. Before analysis, the samples were freeze-dried, finely ground and treated with hydrochloric acid $(\mathrm{HCl})$ for TOC measurements (TUNG \& TANNER, 2003). Calculation of TIC is based on the difference between total carbon (TC) (untreated samples) and TOC (samples treated with $\mathrm{HCl}$ ). $\mathrm{C} / \mathrm{N}$ ratio was calculated from TOC and $\mathrm{N}$ measurements.

Elemental analysis was carried out on ground samples using Inductively Coupled Plasma-Mass Spectrometry (ICP-MS) in the ACME laboratory, Canada. Geochemical data was analysed using multivariate statistical techniques. Discriminant function analysis (DFA) included a selection of geochemical compositions (TOC, TIC, N, Ca, Mg, Fe, K, Al, P, S, Cu, Pb and Mo) and a single ratio $(\mathrm{C} / \mathrm{N})$. Results of the geochemical analysis represent a typical example of compositional data $(\mathrm{CoDa})$ where correlations between relative elemental abundances may not be unequivocal in the absence of any other information or assumptions (LOVELL et al., 2015). A detailed description of CoDa analysis is reported elsewhere (PEH \& KOVAČEVIĆ GALOVIĆ, 2014; PEH \& KOVAČEVIĆ GALOVIĆ, 2016; GALOVIĆ \& PEH, 2016; ŠORŠA et al., 2018), with sample references to the original explanations from the Research Group on CoDa Analysis (Girona).

Discriminant function analysis (DFA) is a traditional multivariate statistical technique which is particularly useful in building the predictive model for the two- or multiple-group discrimination based on the suite of independent (predictor) variables. It 
Table 2. Measured water parameters in the investigated environments.

\begin{tabular}{|c|c|c|c|c|c|c|}
\hline Core location & Core & Date of measurement & $\mathrm{Ec}(\mathrm{mS} / \mathrm{cm})$ & $\mathrm{pH}$ & $\mathrm{O}_{2}(\mathrm{mg} / \mathrm{l})$ & Temperature $\left({ }^{\circ} \mathrm{C}\right)$ \\
\hline Jaz & LK-2 & 09/09/2015 & 56 & 8.39 & 13.33 & 23 \\
\hline Sonte & LK-3 & 09/09/2015 & 55.5 & 8.24 & 9.11 & 21.9 \\
\hline Marinska & LK-5 & $10 / 09 / 2015$ & 11.1 & 8.36 & 15.12 & 28.1 \\
\hline Arcij & LK-6 & $10 / 09 / 2015$ & 49.1 & 8.75 & 15.22 & 22.7 \\
\hline Podbrajde & LK-7 & 09/09/2015 & 56.8 & 9.07 & 14.73 & 23.9 \\
\hline
\end{tabular}

is commonly exercised in geo- and environmental sciences when geological logic calls for the use of some autonomous criterion with regards to the variables in the analysed dataset, such as, in this case, the multi-proxy sediment core data analysis. Objectives and principles of DFA are described comprehensively in many statistical textbooks (e.g., DAVIS, 1973; DAVIS, 1986; DILLON \& GOLDSTEIN, 1984; ROCK, 1988; REIMANN et al., 2008). Geochemical data were processed using the statistical software package of STATISTICA 10 (STATSOFT, 2011) in the spirit of the CoDa analysis.

\section{RESULTS}

\subsection{Physical and chemical water parameters}

The investigated environments showed variability of the measured physical and chemical water parameters. Table 2. shows conductivity $\left(\mathrm{E}_{\mathrm{c}}\right), \mathrm{pH}$, temperature $(\mathrm{t})$ and dissolved oxygen $\left(\mathrm{O}_{2}\right)$ concentrations. The $\mathrm{E}_{\mathrm{c}}$ measurements reveal significant differences, with the lowest $\mathrm{E}_{\mathrm{c}}$ values in the Marinska marine pond (11.1 $\mathrm{mS} / \mathrm{cm})$ and the highest in the Podbrajde marine pond $(56.8 \mathrm{mS} /$ $\mathrm{cm}$ ). The $\mathrm{pH}$ ranged from 8.24 (Sonte embayment) to 9.07 (Podbrajde marine pond). Measured $\mathrm{O}_{2}$ concentrations varied from $9.11 \mathrm{mg} / \mathrm{l}$ in the Sonte embayment up to $15.22 \mathrm{mg} / \mathrm{l}$ in the Arcij marine pond. The highest temperature of $28.1^{\circ} \mathrm{C}$ was determined in the Marinska pond.

\subsection{Sediment core analysis}

Since the cores from marine ponds (LK-5, LK-6 and LK-7) are short (up to $45.5 \mathrm{~cm}$ ) and analysis of the foraminiferal assemblages focused only on the core tops, we did not section them into distinct units (Figs. 2 to 4). Based on the sediment characteristics such as grain-size, TOC, TIC and N content, and the geochemistry of selected major and trace elements several units were dif-
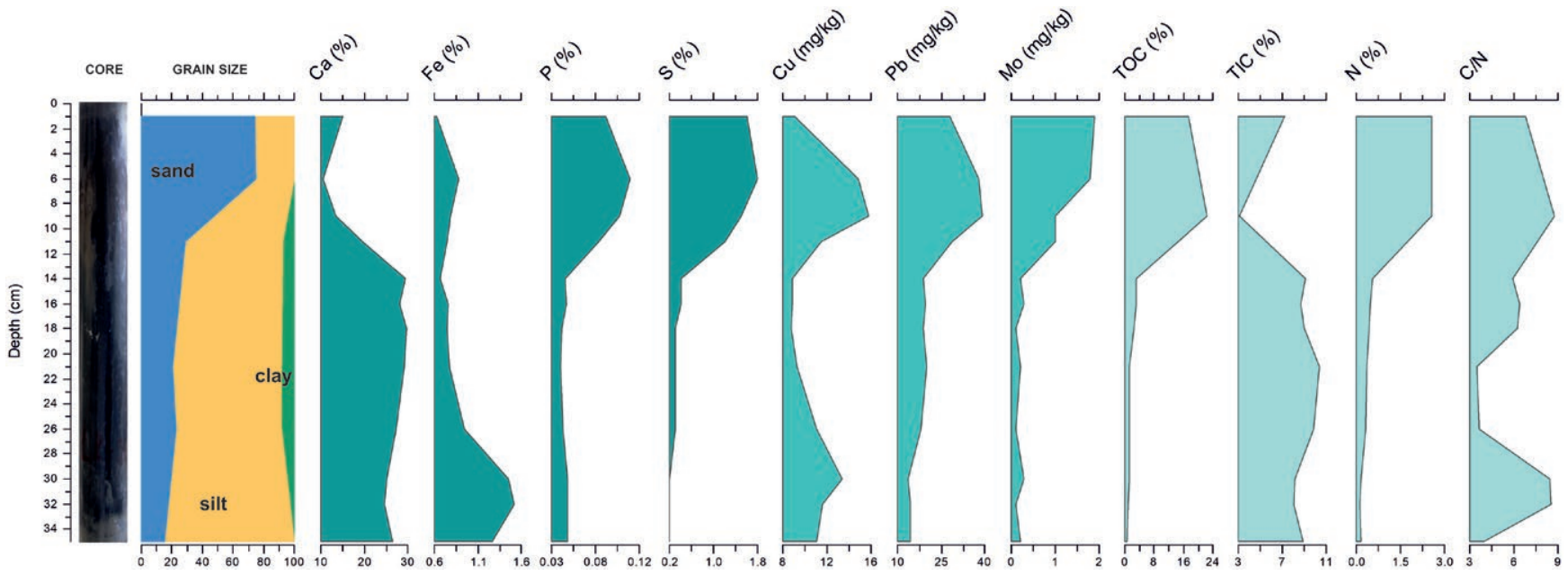

Figure 2. Downcore variations of sedimentological and geochemical parameters in the sediment core LK-5 collected in the Marinska marine pond.

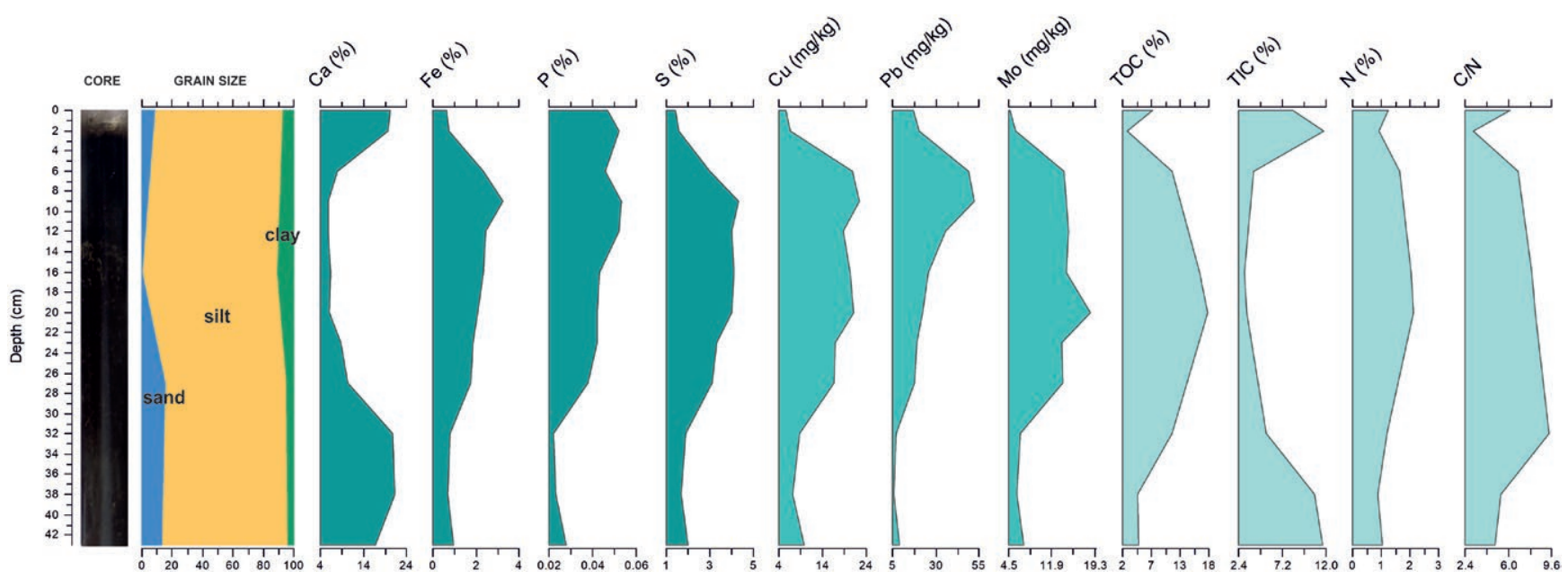

Figure 3. Downcore variations of sedimentological and geochemical parameters in the sediment core LK-6 collected in the Arcij marine pond. 

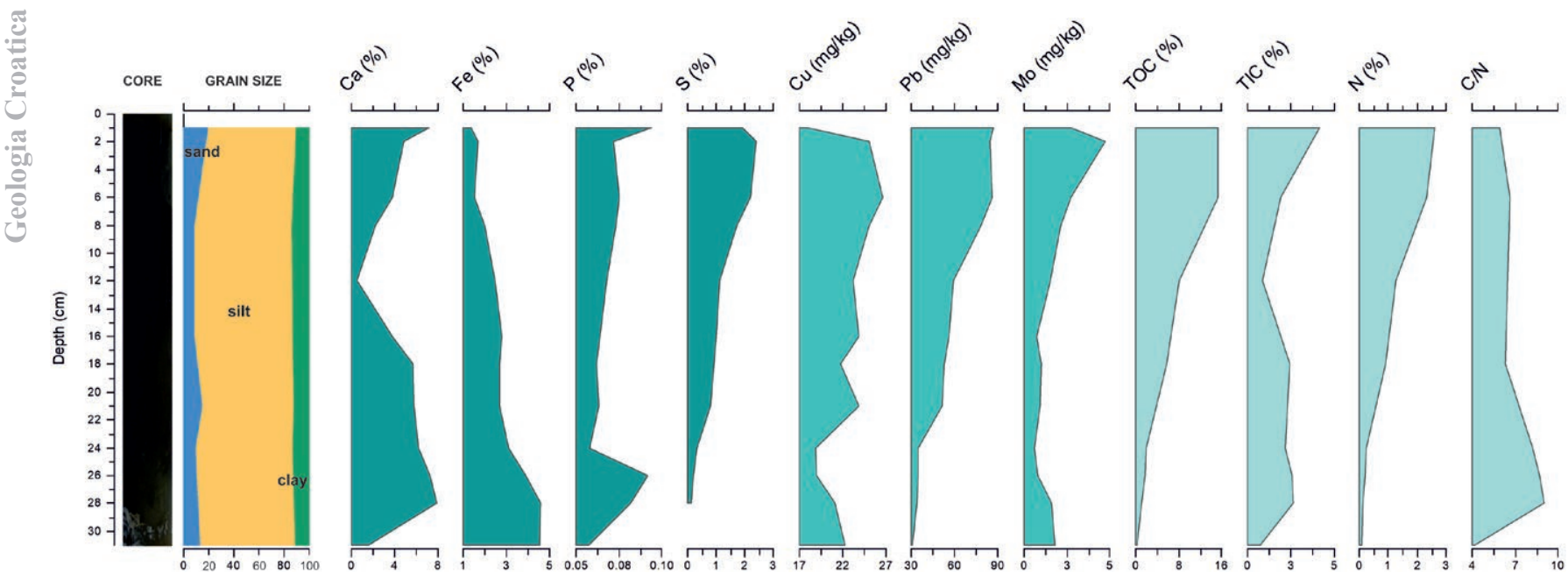

Figure 4. Downcore variations of sedimentological and geochemical parameters in the sediment core LK-7 collected in the Podbrajde marine pond.

ferentiated in the longer sediment cores LK-2 and LK-3 from the Jaz and Sonte embayments, respectively (Figs. 5 and 6).

In the LK-2 core two different units were recognized:

1. Unit LK-2-1: $150-60 \mathrm{~cm}$

2. Unit LK-2-2: $60-0 \mathrm{~cm}$

The LK-3 core can be divided into four distinct units:

1. Unit LK-3-1: $371-330 \mathrm{~cm}$

2. Unit LK-3-2: 330-260 cm

3. Unit LK-3-3: $260-50 \mathrm{~cm}$

4. Unit LK-3-4: 50-0 cm below.

The main features of the differentiated units are emphasized

\subsubsection{Core chronology}

The radiocarbon data obtained from the macrofossils of the piston cores LK-2 and LK-3 is shown in Table 3. The sediment sequence in both cores is of Holocene age and spans $>6610$ years in core LK-3 and $>711$ years in core LK-2. Age reversal has been found in sediment core LK-3, with the result at the core depth of $354 \mathrm{~cm}$ being younger than the samples at $252 \mathrm{~cm}$ and $217 \mathrm{~cm}$.
Due to the fact that results at 252 and $217 \mathrm{~cm}$ have been obtained on single mollusc shells each and the result at $354 \mathrm{~cm}$ has been obtained on mixed shells of gastropods and bivalves, the former are thought to be more reliable. Therefore, the result at $354 \mathrm{~cm}$ has been discarded (Tab. 3).

\subsubsection{Grain size analysis}

Grain-size analysis on 110 samples from all sediment cores revealed variations in the grain-size both between cores and within particular cores (Figs. 2 to 6, Tab. 4). Core tops are predominantly composed of coarse silt to medium sand. In most cores grain-size slightly decreases downwards with the general predominance of silty material (Figs. 2 to 6 ).

The highest sand abundance has been measured in the core LK-5 (<75\%). Generally, a significant amount of silty material $(25-85 \%)$ has also been deposited, while the clay fraction (0-9\%) is subordinate. Core LK-6 is predominantly composed of silt (80$88 \%$ ). Core LK-7 also shows a predominance of silty material (70-78\%), while the sand (8-20\%) and clay (11-14\%) fractions are less abundant. Samples from the sediment cores LK-2 and LK-3 have the highest silt content, $41-88 \%$ and $40-91 \%$, respectively.

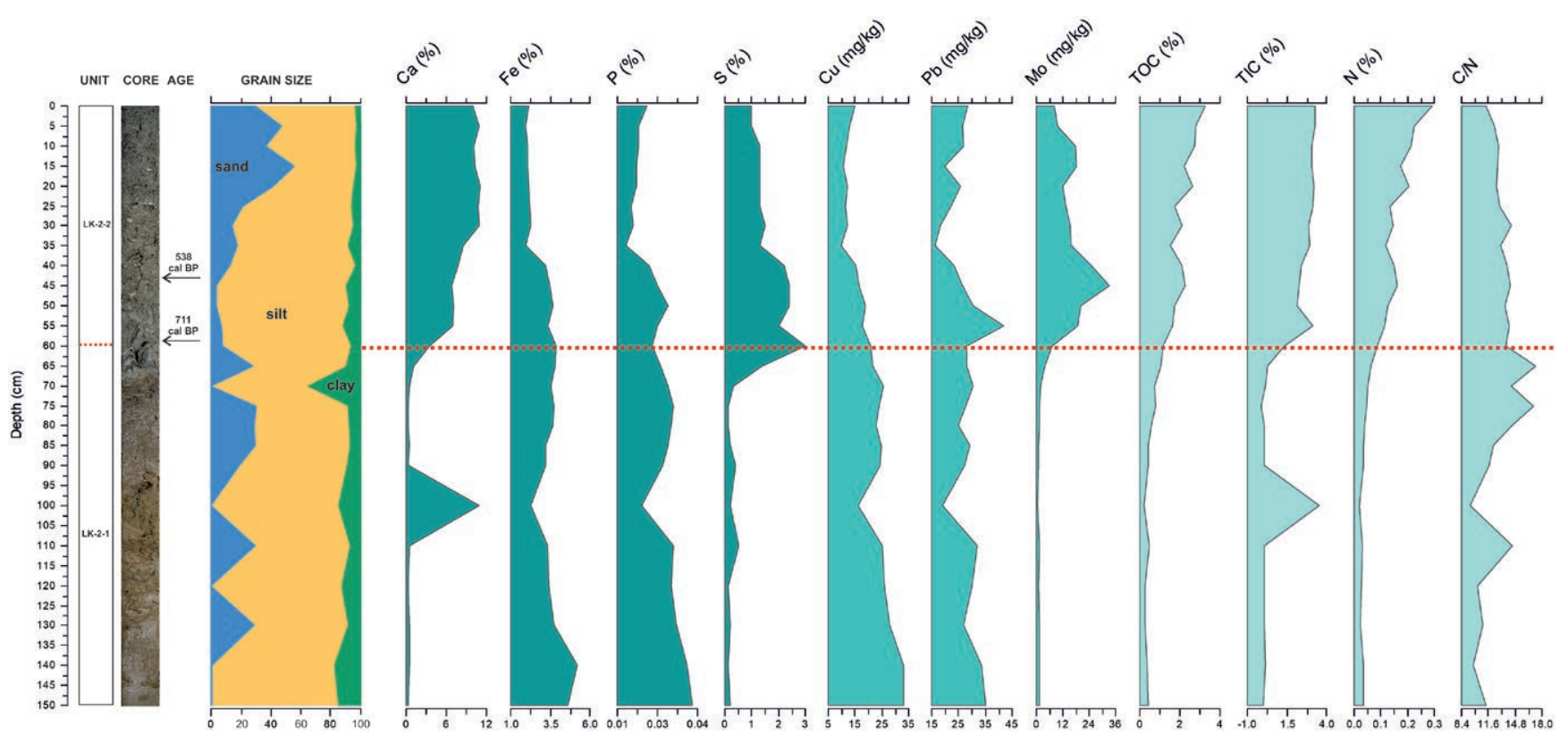

Figure 5. Downcore variations of sedimentological and geochemical parameters in the sediment core LK-2 collected in the Jaz embayment. 

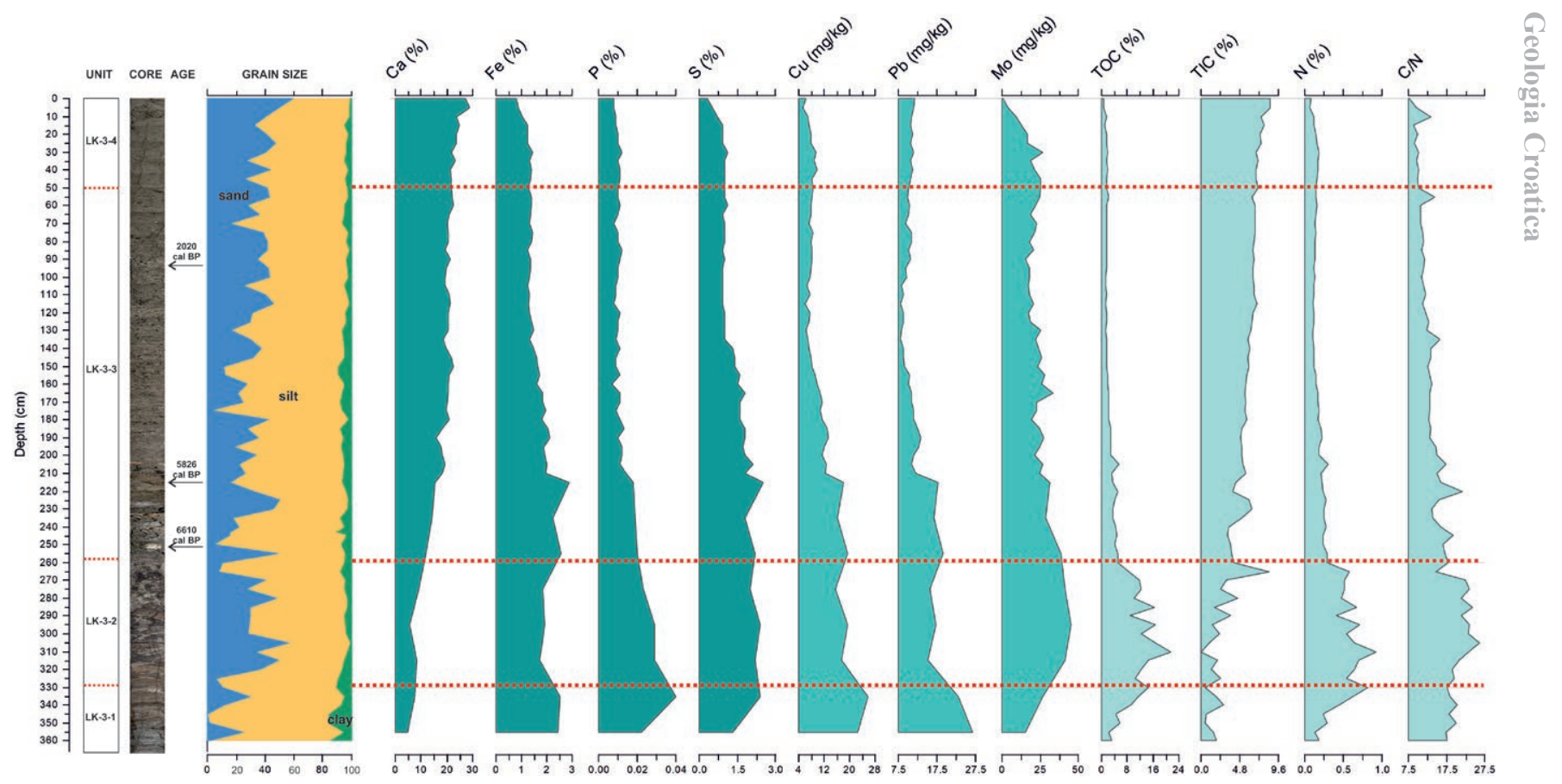

Figure 6. Downcore variations of sedimentological and geochemical parameters in the sediment core LK-3 collected in the Sonte embayment.

\subsubsection{Mineralogical analysis}

Bulk mineralogical analysis of sediment core LK-5 indicates the predominance of calcite and quartz, while aragonite is also abundant. Halite, Mg calcite, aragonite, gypsum, quartz, muscovite/ illite and pyrite are present in sediment core LK-6. Sediment core LK-7 is characterized by the occurrence of halite, quartz, muscovite/illite and calcite. In the sediment cores LK-2 and LK3 , quartz is the dominant mineral phase, while the calcite presence is variable downcore. In the basal part of the LK-2 core quartz, muscovite/illite and kaolinite are abundant (unit LK-2-1). The upper part of the LK-2 core (unit LK-2-2) is characterized by calcite, Mg-calcite, aragonite and halite. Muscovite/illite and plagioclase are present throughout the LK-2 core. The lowermost part of the core LK-3 (unit LK-3-1) shows the presence of quartz, muscovite/illite, chlorite and kaolinite. Calcite and Mg-calcite predominate in the upper part of the core (units LK-3-2, LK-3-3 and LK-3-4). Aragonite, dolomite, halite, plagioclase, muscovite/ illite and kaolinite are less abundant. The presence of halite in all samples is a consequence of its crystallization from the pore water after sediment drying. The same clay minerals (chlorite, illite and kaolinite) characterize all the analysed cores. The only exception is the presence of $\mathrm{Mg}$ clay mineral sepiolite in the sediment core LK-5.

\subsubsection{Foraminiferal analysis}

Overall, 87 different species were identified in the total foraminiferal assemblages (all cores). Samples from cores LK-5, LK-6 and LK-7 were less diverse and encompass 13 species. In the samples from the sediment cores LK-2 and LK-3, 81 foraminiferal species were determined. One sample (LK-2-1, 67-68 cm) did not contain foraminifera, while in the samples from the basal part of LK-3 core (unit LK-3-1) and from LK-7 core foraminifera specimens were scarce and poorly preserved.

The first $\mathrm{cm}$ of sediment core LK-5 includes only agglutinated taxa. No live specimens were recognized. Dominant species are Haplophragmoides canariensis (48\%) and Trochammina inflata (41\%), while Miliammina fusca and Entzia macrescens are significantly less abundant (Tab. 5; Plate 1). In the LK-6 core top sample Ammonia tepida specimens predominate (97\%) (Tab. 5; Plate 1). In total, 37 stained specimens were recognized in this sample, while 6 stained specimens showed morphological abnormalities, including enlarged chambers and twisted coiling (Plate 1). Only 7 foraminifera specimens were discovered in the first $\mathrm{cm}$ of core LK-7 collected in the Podbrajde marine pond (Tab. 5).

The lower part of the LK-2 core was barren of foraminifera (unit LK-2-1), while the gradual occurrence of foraminifera specimens was observed at core depth of $62-63 \mathrm{~cm}$. Foraminifera

Table 3. AMS ${ }^{14} \mathrm{C}$ dating results of mollusc shells in sediment cores LK-2 and LK-3. The last result (marked with asterisk) has been discarded.

\begin{tabular}{|c|c|c|c|c|c|c|}
\hline Core & Depth $(\mathrm{cm})$ & Sample ID & Material dated & $\begin{array}{c}\text { Conventional radiocarbon } \\
\text { age }\left({ }^{14} \mathrm{C} \mathrm{BP}\right)\end{array}$ & Probability (\%) & Calibrated age (cal BP) \\
\hline \multirow{2}{*}{ LK-2 } & \multirow{2}{*}{42} & \multirow{2}{*}{ Beta - 387747} & \multirow{2}{*}{ bivalve shell } & \multirow{2}{*}{$1000 \pm 30$} & 50 & $506-571$ \\
\hline & & & & & 44.7 & $580-651$ \\
\hline \multirow{2}{*}{ LK-2 } & \multirow{2}{*}{58} & \multirow{2}{*}{ Beta - 387748} & \multirow{2}{*}{ bivalve shell } & \multirow{2}{*}{$1200 \pm 30$} & 88 & $641-782$ \\
\hline & & & & & 6.9 & $564-590$ \\
\hline LK-3 & 94 & Beta - 387749 & gastropod shell & $2510 \pm 30$ & 95 & $1892-2148$ \\
\hline LK-3 & 252 & Beta - 387751 & bivalve shell & $6260 \pm 30$ & 95 & $6483-6737$ \\
\hline LK-3* & 354 & Beta - 387752 & bivalve and gastropod shell & $4000 \pm 30$ & 95 & $3693-3976$ \\
\hline
\end{tabular}


Table 4. Statistical parameters for the physicochemical characterisation of sediment cores.

\begin{tabular}{|c|c|c|c|c|c|c|c|c|c|c|}
\hline & & LK-5 & LK-6 & LK-7 & LK-2-1 & LK-2-2 & LK-3-1 & LK-3-2 & LK-3-3 & LK-3-4 \\
\hline \multirow{4}{*}{$\mathrm{Ca}(\%)$} & Mean & 23.27 & 12.52 & 4.72 & 1.33 & 8.82 & 6.19 & 7.65 & 19.54 & 23.73 \\
\hline & SD & 6.85 & 6.65 & 2.39 & 3.03 & 2.27 & 1.90 & 2.02 & 2.26 & 2.36 \\
\hline & Min & 10.53 & 5.83 & 0.56 & 0.31 & 3.55 & 4.85 & 5.35 & 11.97 & 21.46 \\
\hline & Max & 29.77 & 21.38 & 7.88 & 10.93 & 11.12 & 7.53 & 9.15 & 22.40 & 28.67 \\
\hline \multirow{4}{*}{ Mg (\%) } & Mean & 0.91 & 1.28 & 1.06 & 0.64 & 0.78 & 0.91 & 1.20 & 1.08 & 1.05 \\
\hline & SD & 0.06 & 0.19 & 0.29 & 0.09 & 0.16 & 0.08 & 0.05 & 0.09 & 0.07 \\
\hline & Min & 0.81 & 1.09 & 0.68 & 0.46 & 0.63 & 0.85 & 1.17 & 0.92 & 0.92 \\
\hline & Max & 1.02 & 1.68 & 1.50 & 0.82 & 1.05 & 0.97 & 1.26 & 1.26 & 1.18 \\
\hline \multirow{4}{*}{$\mathrm{Fe}(\%)$} & Mean & 0.93 & 1.67 & 2.77 & 3.65 & 2.63 & 2.48 & 1.83 & 1.65 & 1.20 \\
\hline & SD & 0.31 & 0.87 & 1.09 & 0.73 & 0.74 & 0.05 & 0.10 & 0.39 & 0.21 \\
\hline & Min & 0.63 & 0.66 & 1.38 & 2.28 & 1.92 & 2.44 & 1.73 & 1.24 & 0.79 \\
\hline & Max & 1.52 & 3.25 & 4.57 & 5.22 & 3.89 & 2.51 & 1.92 & 2.89 & 1.43 \\
\hline \multirow{4}{*}{ K (\%) } & Mean & 0.51 & 0.59 & 1.24 & 1.57 & 0.99 & 1.37 & 0.91 & 0.65 & 0.50 \\
\hline & SD & 0.17 & 0.24 & 0.35 & 0.26 & 0.27 & 0.12 & 0.06 & 0.16 & 0.10 \\
\hline & Min & 0.22 & 0.33 & 0.60 & 0.93 & 0.71 & 1.28 & 0.86 & 0.51 & 0.31 \\
\hline & Max & 0.75 & 1.02 & 1.58 & 1.96 & 1.48 & 1.45 & 0.98 & 1.12 & 0.62 \\
\hline \multirow{4}{*}{$\mathrm{Al}(\%)$} & Mean & 2.05 & 2.21 & 4.97 & 6.84 & 4.27 & 6.21 & 4.14 & 2.86 & 2.03 \\
\hline & SD & 0.69 & 1.05 & 1.79 & 1.29 & 1.24 & 0.12 & 0.44 & 0.84 & 0.44 \\
\hline & Min & 0.80 & 0.98 & 1.83 & 4.21 & 3.03 & 6.12 & 3.73 & 2.05 & 1.19 \\
\hline & Max & 3.07 & 4.13 & 7.26 & 9.25 & 6.27 & 6.29 & 4.61 & 5.21 & 2.59 \\
\hline \multirow{4}{*}{$\mathrm{P}(\%)$} & Mean & 0.06 & 0.04 & 0.07 & 0.03 & 0.02 & 0.03 & 0.03 & 0.01 & 0.01 \\
\hline & SD & 0.03 & 0.01 & 0.01 & 0.00 & 0.00 & 0.01 & 0.00 & 0.00 & 0.00 \\
\hline & Min & 0.04 & 0.02 & 0.06 & 0.02 & 0.01 & 0.02 & 0.02 & 0.01 & 0.01 \\
\hline & Max & 0.11 & 0.05 & 0.09 & 0.04 & 0.03 & 0.04 & 0.03 & 0.02 & 0.01 \\
\hline \multirow{4}{*}{ S (\%) } & Mean & 0.70 & 2.87 & 1.06 & 0.32 & 1.69 & 1.85 & 2.20 & 1.36 & 0.85 \\
\hline & SD & 0.63 & 1.10 & 0.82 & 0.36 & 0.63 & 0.78 & 0.20 & 0.45 & 0.25 \\
\hline & Min & 0.20 & 1.40 & 0.10 & 0.10 & 1.00 & 1.30 & 2.00 & 0.90 & 0.30 \\
\hline & Max & 1.80 & 4.30 & 2.40 & 1.40 & 3.00 & 2.40 & 2.40 & 2.50 & 1.10 \\
\hline \multirow{4}{*}{$\mathrm{Cu}(\mathrm{mg} / \mathrm{kg})$} & Mean & 11.15 & 14.53 & 22.37 & 25.41 & 14.22 & 24.25 & 17.43 & 9.73 & 7.78 \\
\hline & SD & 2.44 & 6.42 & 2.74 & 4.65 & 3.37 & 2.33 & 1.85 & 3.30 & 1.35 \\
\hline & Min & 8.70 & 5.70 & 17.90 & 16.10 & 9.90 & 22.60 & 15.60 & 6.00 & 5.30 \\
\hline & Max & 15.80 & 22.30 & 26.60 & 33.20 & 20.80 & 25.90 & 19.30 & 19.40 & 9.60 \\
\hline \multirow{4}{*}{$\mathrm{Pb}(\mathrm{mg} / \mathrm{kg})$} & Mean & 22.61 & 23.41 & 57.36 & 28.66 & 25.63 & 24.90 & 16.00 & 10.81 & 10.98 \\
\hline & SD & 8.82 & 15.15 & 21.71 & 4.18 & 6.53 & 2.69 & 1.06 & 2.60 & 0.46 \\
\hline & Min & 13.60 & 5.80 & 30.40 & 19.10 & 16.10 & 23.00 & 15.20 & 7.90 & 10.20 \\
\hline & Max & 39.10 & 52.10 & 86.80 & 35.00 & 42.00 & 26.80 & 17.20 & 19.20 & 11.60 \\
\hline & Mean & 0.60 & 11.05 & 1.76 & 1.43 & 16.48 & 20.85 & 42.67 & 23.15 & 16.12 \\
\hline & SD & 0.66 & 4.74 & 1.18 & 0.76 & 7.13 & 8.27 & 2.20 & 4.98 & 8.62 \\
\hline Mo (mg/kg) & Min & 0.10 & 4.60 & 0.60 & 0.60 & 7.10 & 15.00 & 41.30 & 15.30 & 0.70 \\
\hline & Max & 1.90 & 18.60 & 4.70 & 3.60 & 33.10 & 26.70 & 45.20 & 38.60 & 26.60 \\
\hline & Mean & 5.40 & 9.58 & 6.24 & 0.50 & 2.14 & 6.00 & 13.34 & 2.51 & 1.38 \\
\hline TOC (\%) & SD & 7.78 & 5.49 & 6.22 & 0.25 & 0.59 & 3.54 & 3.62 & 1.26 & 0.41 \\
\hline $10(\%)$ & Min & 0.65 & 2.76 & 0.31 & 0.20 & 1.17 & 2.26 & 8.44 & 1.18 & 0.61 \\
\hline & Max & 22.38 & 17.72 & 15.42 & 1.06 & 3.28 & 11.35 & 21.42 & 5.22 & 1.81 \\
\hline & Mean & 8.24 & 7.30 & 2.19 & 0.36 & 2.77 & 1.54 & 2.48 & 5.62 & 7.42 \\
\hline TC (0\%) & SD & 2.02 & 3.79 & 1.08 & 1.01 & 0.58 & 0.85 & 2.12 & 1.02 & 0.64 \\
\hline ЖL (\%) & Min & 3.07 & 3.03 & 0.74 & bdl & 1.30 & 0.55 & 0.05 & 3.23 & 6.76 \\
\hline & Max & 10.34 & 11.80 & 4.16 & 3.56 & 3.30 & 2.81 & 8.52 & 7.00 & 8.57 \\
\hline & Mean & 0.77 & 1.39 & 0.97 & 0.04 & 0.16 & 0.32 & 0.62 & 0.18 & 0.14 \\
\hline N(0) & SD & 0.96 & 0.49 & 1.02 & 0.01 & 0.06 & 0.18 & 0.14 & 0.06 & 0.04 \\
\hline $\mathrm{IN}(\%)$ & Min & 0.12 & 0.90 & 0.07 & 0.02 & 0.08 & 0.13 & 0.41 & 0.10 & 0.07 \\
\hline & Max & 2.57 & 2.13 & 2.60 & 0.06 & 0.29 & 0.61 & 0.92 & 0.30 & 0.18 \\
\hline & Mean & 6.22 & 6.49 & 6.93 & 12.77 & 13.20 & 18.70 & 21.50 & 13.74 & 9.86 \\
\hline$C / N$ & SD & 2.01 & 2.07 & 1.64 & 2.67 & 0.85 & 1.23 & 2.97 & 2.48 & 1.41 \\
\hline $\mathrm{C} / \mathrm{N}$ & Min & 3.49 & 3.04 & 4.14 & 9.46 & 11.30 & 17.35 & 14.74 & 10.66 & 7.65 \\
\hline & Max & 8.78 & 9.38 & 9.04 & 17.25 & 14.28 & 20.36 & 26.17 & 21.69 & 13.41 \\
\hline & Mean & 39.26 & 9.00 & 12.14 & 16.25 & 22.95 & 11.82 & 30.92 & 28.68 & 40.75 \\
\hline SAND (0\%) & SD & 27.53 & 6.63 & 4.41 & 14.41 & 17.57 & 12.96 & 15.78 & 12.53 & 9.89 \\
\hline SAIVD (\%) & Min & 15.16 & 0.06 & 8.25 & 0.00 & 3.25 & 0.02 & 5.94 & 2.18 & 25.53 \\
\hline & Max & 74.67 & 14.77 & 19.53 & 30.22 & 55.76 & 29.91 & 56.13 & 50.35 & 59.45 \\
\hline & Mean & 56.74 & 83.82 & 75.07 & 70.43 & 70.67 & 77.12 & 63.52 & 65.87 & 55.92 \\
\hline SIT (\%) & SD & 25.05 & 3.59 & 3.21 & 10.53 & 15.63 & 8.26 & 13.54 & 10.93 & 8.75 \\
\hline SILI (\%) & Min & 25.33 & 80.18 & 69.78 & 61.12 & 40.81 & 64.42 & 42.71 & 46.76 & 39.70 \\
\hline & Max & 84.84 & 88.37 & 78.35 & 86.62 & 88.23 & 84.25 & 84.10 & 90.81 & 69.93 \\
\hline & Mean & 4.00 & 7.18 & 12.79 & 13.32 & 6.39 & 11.07 & 5.56 & 5.45 & 3.33 \\
\hline & SD & 4.40 & 3.11 & 1.28 & 8.10 & 2.87 & 5.28 & 2.75 & 2.22 & 1.47 \\
\hline CLAY (\%) & Min & 0.00 & 4.90 & 10.68 & 7.37 & 3.20 & 5.67 & 1.17 & 1.94 & 0.85 \\
\hline & Max & 8.70 & 11.57 & 14.17 & 36.46 & 12.27 & 16.79 & 10.80 & 11.55 & 5.40 \\
\hline
\end{tabular}




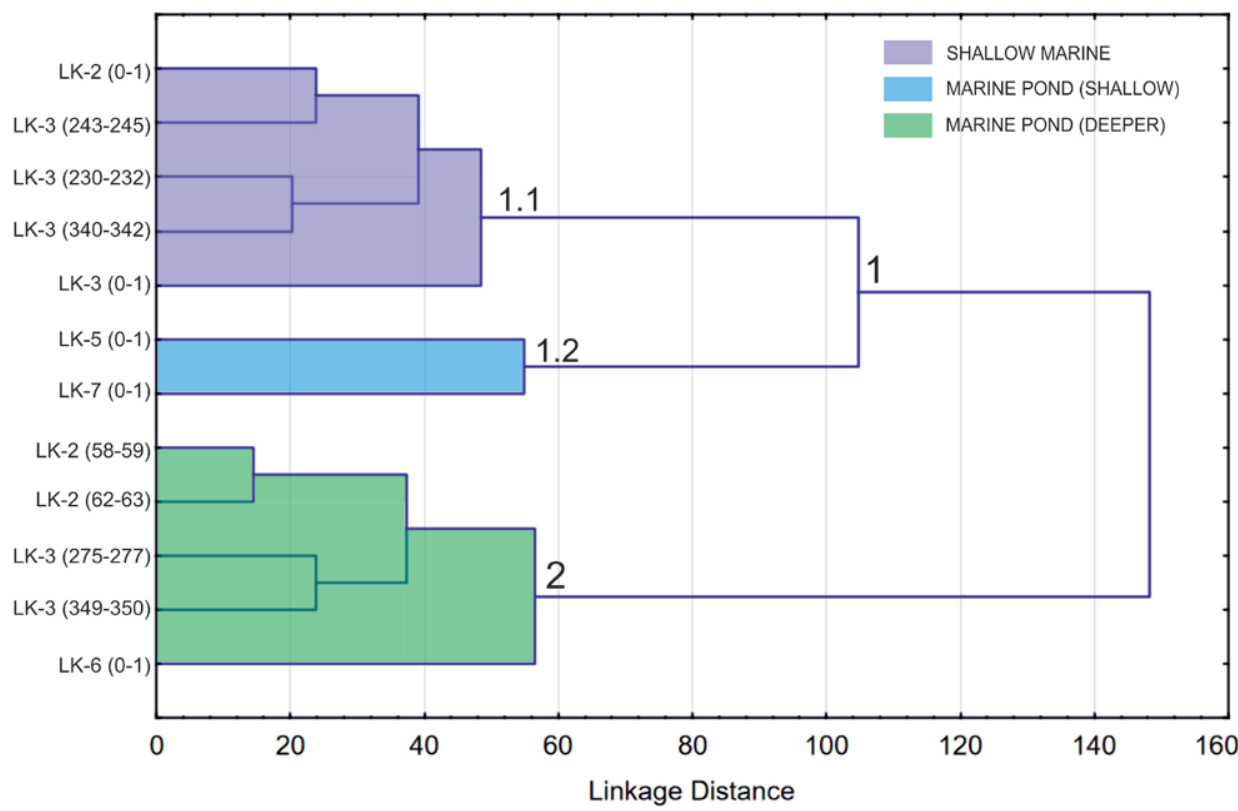

Figure 7. Cluster dendrogram developed based on the foraminiferal analysis results using Ward's method and Euclidean distances.

abundances significantly increased at 58-59 cm (unit LK-2-2), with the predominance of $A$. tepida (39\%) (Tab. 5). In the surface sample from this core different Ammonia species predominate (up to 51\%), while Elphidium margaritaceum, Bolivina striatula, Haynesina depressula and Elphidium translucens are less abundant (Tab. 5, Plate 2).
Samples from sediment core LK-3 also indicate the transition from intervals barren of foraminifera (unit LK-3-1) to their significant diversification (unit LK-3-4) (Tab. 5). The predominance of A. tepida (6-46\%) and Cribroelphidium gerthi (0-21\%) has been observed in all samples from the basal part of the core (unit LK-3-2) (Tab. 5). Miliolids (Quinqueloculina parvula and

Table 5. The relative abundances of the foraminiferal species in sediment cores LK-5, LK-6, LK-7, LK-2 and LK-3. Sample from the LK-2 core interval $62-63 \mathrm{~cm}$ corresponds to unit LK-2-1, while samples $0-1 \mathrm{~cm}$ and $58-59 \mathrm{~cm}$ correspond to unit LK-2-2. The LK-3 core samples belong to the following units: $349-350 \mathrm{~cm}, 340-342$ $\mathrm{cm}$ - unit LK-3-1; 275-277 cm - unit LK-3-2; 243-245 cm and 230-232 cm - unit LK-3-3; 0-1 cm - unit LK-3-4.

\begin{tabular}{|c|c|c|c|c|c|c|c|c|c|c|c|c|}
\hline \multirow{2}{*}{ Foraminifera (species) } & \multirow{2}{*}{$\begin{array}{c}\text { LK-5 } \\
0-1\end{array}$} & \multirow{2}{*}{$\begin{array}{c}\text { LK-6 } \\
0-1\end{array}$} & \multirow{2}{*}{$\begin{array}{c}\text { LK-7 } \\
0-1\end{array}$} & \multicolumn{3}{|l|}{ LK-2 } & \multicolumn{6}{|l|}{ LK-3 } \\
\hline & & & & $0-1$ & $58-59$ & $62-63$ & $0-1$ & $230-232$ & $243-245$ & $275-277$ & $340-342$ & $349-350$ \\
\hline Adelosina carinata-striata & 0.0 & 0.0 & 0.0 & 0.4 & 0.0 & 0.0 & 0.4 & 1.2 & 2.5 & 0.3 & 0.0 & 0.0 \\
\hline Adelosina cliarensis & 0.0 & 0.0 & 0.0 & 0.0 & 0.0 & 0.0 & 0.4 & 1.8 & 0.0 & 0.0 & 0.0 & 0.0 \\
\hline Adelosina elegans & 0.0 & 0.0 & 0.0 & 0.0 & 0.0 & 0.0 & 0.0 & 0.0 & 0.0 & 0.0 & 0.4 & 0.0 \\
\hline Adelosina mediterranensis & 0.0 & 0.0 & 0.0 & 0.0 & 0.0 & 0.0 & 0.7 & 0.0 & 0.0 & 0.0 & 0.0 & 0.0 \\
\hline Ammonia sp. & 0.0 & 0.0 & 14.3 & 12.4 & 1.0 & 4.0 & 0.0 & 0.6 & 8.8 & 1.2 & 0.0 & 0.0 \\
\hline Ammonia beccarii & 0.0 & 0.3 & 0.0 & 0.0 & 0.0 & 0.0 & 0.0 & 3.9 & 0.4 & 6.7 & 6.1 & 6.3 \\
\hline Ammonia parkinsoniana & 0.0 & 1.7 & 0.0 & 15.7 & 8.2 & 4.0 & 0.7 & 0.3 & 3.2 & 3.9 & 0.0 & 12.5 \\
\hline Ammonia tepida & 0.0 & 96.6 & 14.3 & 22.6 & 61.6 & 68.0 & 4.7 & 28.4 & 27.4 & 46.4 & 23.1 & 43.8 \\
\hline Asterigerinata adriatica & 0.0 & 0.0 & 0.0 & 0.0 & 0.0 & 0.0 & 0.0 & 0.0 & 0.0 & 1.5 & 4.4 & 12.5 \\
\hline Asterigerinata mamilla & 0.0 & 0.0 & 0.0 & 2.2 & 0.3 & 0.0 & 9.4 & 2.1 & 1.1 & 0.0 & 0.0 & 0.0 \\
\hline Aubignyna perlucida & 0.0 & 0.0 & 0.0 & 0.4 & 2.0 & 0.0 & 0.7 & 0.3 & 0.4 & 0.3 & 0.4 & 0.0 \\
\hline Bolivina sp.1 & 0.0 & 0.0 & 0.0 & 0.0 & 0.0 & 0.0 & 0.0 & 0.9 & 0.0 & 0.0 & 0.0 & 0.0 \\
\hline Bolivina sp.2 & 0.0 & 0.0 & 0.0 & 0.0 & 0.0 & 0.0 & 0.0 & 0.0 & 0.0 & 0.3 & 0.0 & 0.0 \\
\hline Bolivina difformis & 0.0 & 0.0 & 0.0 & 0.0 & 0.0 & 0.0 & 0.0 & 0.0 & 0.0 & 0.0 & 0.4 & 0.0 \\
\hline Bolivina pseudoplicata & 0.0 & 0.0 & 0.0 & 0.7 & 0.0 & 0.0 & 5.4 & 0.3 & 0.0 & 0.6 & 0.0 & 0.0 \\
\hline Bolivina spathulata & 0.0 & 0.0 & 0.0 & 0.0 & 0.0 & 0.0 & 1.4 & 0.0 & 0.0 & 0.0 & 0.0 & 0.0 \\
\hline Bolivina striatula & 0.0 & 0.0 & 0.0 & 4.0 & 3.3 & 0.0 & 0.7 & 0.0 & 0.0 & 0.0 & 0.0 & 0.0 \\
\hline Bolivina variabilis & 0.0 & 0.0 & 0.0 & 0.0 & 0.0 & 0.0 & 0.0 & 0.3 & 1.4 & 0.0 & 0.0 & 0.0 \\
\hline Buccella sp.2 & 0.0 & 0.0 & 0.0 & 1.1 & 0.0 & 0.0 & 0.0 & 0.0 & 0.0 & 0.0 & 0.0 & 0.0 \\
\hline Cibicides advenum & 0.0 & 0.0 & 0.0 & 1.5 & 0.0 & 0.0 & 0.0 & 0.0 & 0.0 & 0.0 & 0.0 & 0.0 \\
\hline Cibicides refulgens & 0.0 & 0.0 & 0.0 & 0.4 & 0.0 & 0.0 & 1.1 & 0.0 & 0.4 & 0.0 & 0.9 & 0.0 \\
\hline Cibicidoides variabilis & 0.0 & 0.0 & 0.0 & 0.4 & 0.0 & 0.0 & 0.0 & 0.0 & 0.0 & 0.0 & 0.0 & 0.0 \\
\hline Cornuspira involvens & 0.0 & 0.0 & 0.0 & 0.0 & 0.0 & 0.0 & 2.5 & 0.0 & 0.0 & 0.0 & 0.0 & 0.0 \\
\hline Cribroelphidium excavatum & 0.0 & 0.3 & 0.0 & 0.0 & 0.0 & 0.0 & 0.0 & 0.0 & 0.0 & 0.0 & 0.0 & 0.0 \\
\hline Cribroelphidium gerthi & 0.0 & 0.0 & 0.0 & 1.8 & 0.3 & 0.0 & 1.8 & 21.3 & 8.1 & 7.6 & 21.0 & 6.3 \\
\hline
\end{tabular}


Table 5. Continued.

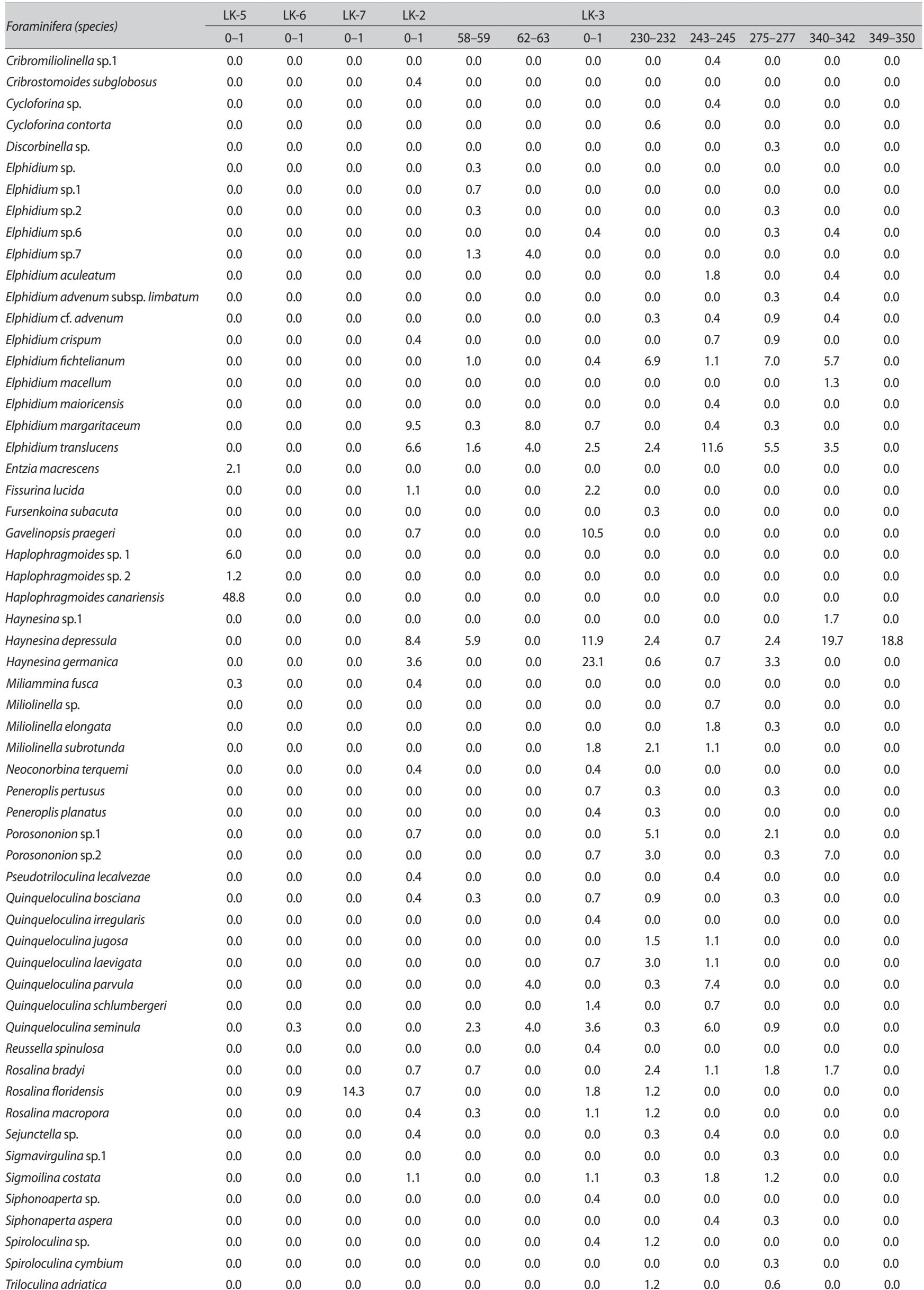


Table 5. Continued.

\begin{tabular}{|c|c|c|c|c|c|c|c|c|c|c|c|c|}
\hline \multirow{2}{*}{ Foraminifera (species) } & LK-5 & LK-6 & LK-7 & LK-2 & & & LK-3 & & & & & \\
\hline & $0-1$ & $0-1$ & $0-1$ & $0-1$ & $58-59$ & $62-63$ & $0-1$ & $230-232$ & $243-245$ & $275-277$ & $340-342$ & $349-350$ \\
\hline Triloculina marioni & 0.0 & 0.0 & 0.0 & 0.0 & 0.0 & 0.0 & 0.0 & 0.0 & 0.4 & 0.0 & 0.0 & 0.0 \\
\hline Triloculina oblonga & 0.0 & 0.0 & 0.0 & 0.0 & 0.0 & 0.0 & 0.0 & 0.3 & 2.8 & 0.3 & 0.0 & 0.0 \\
\hline Trochammina inflata & 41.3 & 0.0 & 42.9 & 0.0 & 0.0 & 0.0 & 0.0 & 0.0 & 0.0 & 0.0 & 0.0 & 0.0 \\
\hline unidentified & 0.3 & 0.0 & 14.3 & 0.4 & 8.2 & 0.0 & 2.5 & 0.3 & 1.8 & 0.6 & 0.9 & 0.0 \\
\hline Number of specimens $(\mathrm{N})$ & 334 & 352 & 7 & 274 & 305 & 25 & 277 & 334 & 285 & 330 & 229 & 16 \\
\hline Number of live specimens (NL) & & 37 & & & & & & & & & & \\
\hline Number of species (S) & 7 & 6 & & 32 & 21 & & 39 & 38 & 38 & 35 & 20 & \\
\hline Dominance (D) & 0.413 & 0.933 & & 0.116 & 0.400 & & 0.098 & 0.141 & 0.116 & 0.238 & 0.152 & \\
\hline Simpson (1-D) & 0.587 & 0.067 & & 0.884 & 0.601 & & 0.902 & 0.859 & 0.884 & 0.762 & 0.848 & \\
\hline Shannon-Wiener (H) & 1.053 & 0.194 & & 2.559 & 1.573 & & 2.849 & 2.609 & 2.734 & 2.235 & 2.207 & \\
\hline Evenness $\left(\mathrm{e}^{\wedge} \mathrm{H} / \mathrm{S}\right)$ & 0.409 & 0.202 & & 0.404 & 0.230 & & 0.443 & 0.358 & 0.405 & 0.267 & 0.454 & \\
\hline Equitability (J) & 0.541 & 0.108 & & 0.738 & 0.517 & & 0.778 & 0.717 & 0.752 & 0.629 & 0.737 & \\
\hline Fisher a & 1.252 & 1.027 & & 9.393 & 5.116 & & 12.4 & 11.04 & 11.78 & 9.90 & 5.27 & \\
\hline
\end{tabular}

Quinqueloculina seminula) become especially abundant at core depths of 243-245 cm (unit LK-3-3). The sample from the first $\mathrm{cm}$ of the core is characterized by the highest abundance of Haynesina germanica (23\%), H. depressula (12\%) and Gavelinopsis praegeri (10\%) (unit LK-3-4) (Tab. 5, Plate 2).

Calculation of the relative species abundances (Tab. 5) revealed that 49 species were abundant at more than $1 \%$ in at least one analysed sample, with only 9 species abundant $>1 \%$ in the LK-5, LK-6 and LK-7 core top samples. Different locations and core depths yielded variablity in the number of species in the samples, from 7 (LK-6 core top) to 41 (LK-3 core top). Samples from cores LK-5, LK-6 and LK-7 were generally less diverse in comparison to samples from cores LK-2 and LK-3. Species richness decreased downcore in the sediment cores LK-2 and LK-3. The same trend was observed in the Fisher $\alpha$ index and Shannon-Wiener index, while Dominance shows the opposite trend. All calculated diversity indices and their variability is shown in Table 5.

Cluster analysis indicated the existence of two clusters (Fig. 7). Cluster 1 encompasses two subclusters (1.1 and 1.2). Subcluster 1.1 includes LK-2 and LK-3 core top samples, and several samples from the middle part of LK-3 core (230-232 cm, 243-245 cm and 340-342 cm). Samples from cores LK-5 and LK-7 were grouped together in subcluster 1.2. Cluster 2 consists of samples from LK-2 core $(62-63 \mathrm{~cm}$ and $58-59 \mathrm{~cm})$, basal part of LK-3 core (349-350 cm and 275-277 cm) and LK-6 core top sample.

Altogether, 52 SEM-EDS analysis were conducted on selected grains of agglutinated taxa from the LK-5 core, while several analysis were performed on calcareous taxa from the first $\mathrm{cm}$ of LK-5 and LK-6 sediment cores. The mineralogical composition of agglutinated taxa is variable. Quartz, amphibole, mica (biotite and muscovite) and feldspars (plagioclase and potassium feldspars) are common mineral phases found in agglutinated foraminiferal tests (Fig. 8).

\subsubsection{Geochemical analysis}

The result of the geochemical analyses is summarized in Table 4. and Figures 2 to 6 . The highest TOC content has been measured in the cores LK-5 (22.38\%), LK-6 (17.72\%) and LK-7 (15.42\%) and samples from the basal part of the sediment core LK-3 (units LK-3-2 and LK-3-1; 21.42\% and 11.35\%, respectively) (Fig. 9I). The highest TIC content has been determined in cores LK-5 $(10.34 \%)$ and LK-6 (11.8\%) and in the samples from the topmost part of the core LK-3 (unit LK-3-4; 8.57\%) (Fig. 9H). The N was most abundant in the cores LK-5 (2.57\%), LK-6 (2.13\%) and LK-7
$(2.6 \%)$, with somewhat lower abundances in the basal part of the LK-3 core (units LK-3-2 and LK-3-1; 0.92\% and 0.61\%, respectively) (Fig.9G). Most of the samples from cores LK-5, LK-6 and LK-7 were characterized by very low $\mathrm{C} / \mathrm{N}$ ratios $(<<12)$, while the highest values of $\mathrm{C} / \mathrm{N}$ ratio $(>12)$ were observed in the samples from the basal part of LK-3 (units LK-3-2 and LK-3-1) (Tab. 4).

The highest calcium (Ca) concentrations were measured in LK-5 core (29.77\%), while the lowest concentrations were observed in LK-2 core (unit LK-2-1; 7.88\%). Magnesium (Mg) has the highest concentrations in core LK-6 (1.68\%), while terrigenous elements $(\mathrm{Fe}, \mathrm{K}, \mathrm{Al})$ are the most abundant in the topmost part of the LK-2 core (unit LK-2-1; e.g., Fe up to 5.22\%) (Fig. 9B). Samples from the LK-5 core have the highest P concentrations $(0.11 \%)$. Furthermore, the highest $\mathrm{Pb}$ concentrations were measured in core LK-7 from Podbrajde pond $(86.8 \mathrm{mg} / \mathrm{kg})$. Molybdenum (Mo) proved to be abundant in most cores $(0.1-45.2 \mathrm{mg} / \mathrm{kg})$, with the highest concentrations measured in the LK-3 core (unit LK-3-2) (Fig. 9D). Sulfur (S) concentrations vary between $0.1 \%$ and $4.3 \%$. The highest $\mathrm{S}$ concentrations were found in core LK-6 (4.3\%) (Tab. 4; Fig. 9E).

\subsubsection{Discriminant function analysis (DFA) of the geochemical data}

Discriminant function analysis (DFA) of geochemical data is summarized in the composite Table 6., describing the geochemical exploratory model for the sediment cores. The table comprises both the multivariate test for the overall significance of discrimination and the test of residual roots (discriminant functions). The Wilks' k statistical test is commonly used with the purpose of validating the probability level $(\mathrm{p}<0.05)$ required to proceed safely with computing discriminant functions (DFs). It is used to select both the statistically significant functions as well as explaining the maximum of the within-group variation. The scatterplots of variable loadings and group centroids are constructed for the first three DFs that explain the greatest proportion of the between-group variance, almost 92\% (Fig. 10). In the computed model the first discriminant function DF1 plays by far the greatest role in discrimination between the groups, accounting for more than $60 \%$ of the total variance (Tab. 6).

In the context of the environmental conditions studied, this multivariate method is particularly helpful in chasing the major sources of between-group differences originating from dissemination of the chemical elements in the sediment cores. In combining the cores from marine ponds (LK-5, LK-6 and LK-7) and 

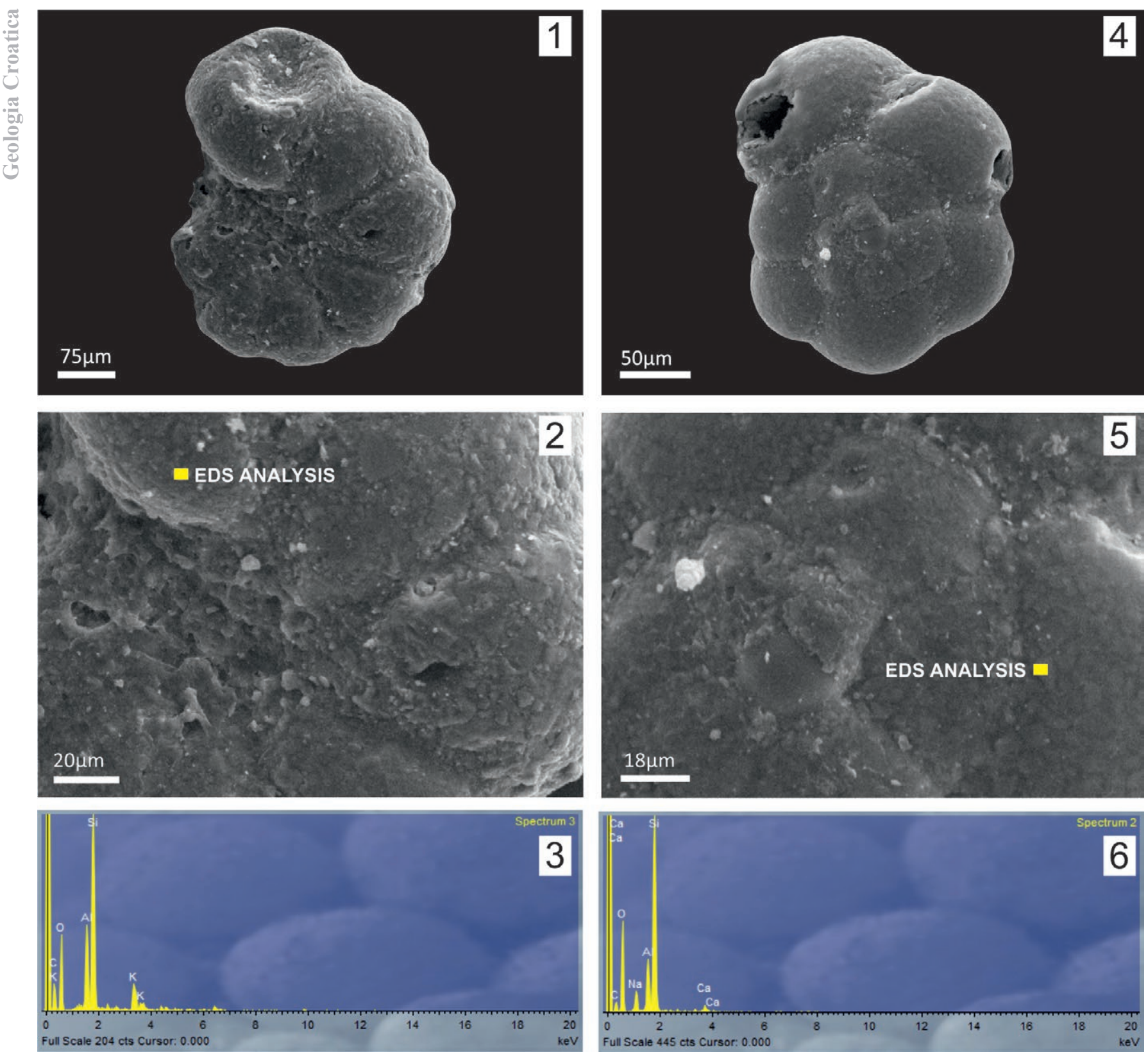

Figure 8. 1-3 Potassium feldspar mineral grain recognized in Haplophragmoides canariensis specimen using the SEM-EDS method; 4-6 Plagioclase mineral grain recognized in Trochammina inflata specimen using the SEM-EDS method.

Table 6. Multivariate test for the overall significance of discrimination and tests of residual roots.

\begin{tabular}{|c|c|c|c|c|c|c|c|}
\hline \multicolumn{4}{|c|}{ No. of variables } & \multicolumn{4}{|c|}{14} \\
\hline \multicolumn{4}{|c|}{ Wilks'lambda } & \multicolumn{4}{|c|}{0.00001} \\
\hline \multicolumn{4}{|c|}{ Approximate $\mathrm{F}$ ratio } & \multicolumn{4}{|c|}{24,968} \\
\hline \multicolumn{4}{|c|}{ Degrees of freedom } & \multicolumn{4}{|c|}{$[112 ; 642]$} \\
\hline \multicolumn{4}{|c|}{ p-level } & \multicolumn{4}{|c|}{$<0.0000$} \\
\hline DF & $\begin{array}{l}\text { Eigen } \\
\text { value }\end{array}$ & Eigen (\%) & $\begin{array}{c}\text { Canon. } \\
\text { R }\end{array}$ & $\begin{array}{c}\text { Wilks' } \\
\text { । }\end{array}$ & $\mathrm{Chi}^{2}$ & df & $\begin{array}{c}\mathrm{p}- \\
\text { level }\end{array}$ \\
\hline 1 & 42,984 & 60.43 & 0.989 & 0.000 & 1170.3 & 112 & 0.000 \\
\hline 2 & 17,966 & 25.26 & 0.973 & 0.000 & 793.8 & 91 & 0.000 \\
\hline 3 & 4,388 & 6.17 & 0.902 & 0.007 & 501.0 & 72 & 0.000 \\
\hline 4 & 2,359 & 3.32 & 0.838 & 0.035 & 333.4 & 55 & 0.000 \\
\hline 5 & 1,988 & 2.80 & 0.816 & 0.118 & 212.9 & 40 & 0.000 \\
\hline 6 & 1,131 & 1.59 & 0.729 & 0.352 & 103.9 & 27 & 0.000 \\
\hline 7 & 0.211 & 0.30 & 0.418 & 0.750 & 28.7 & 16 & 0.026 \\
\hline 8 & 0.101 & 0.14 & 0.303 & 0.908 & 9.6 & 7 & 0.214 \\
\hline
\end{tabular}



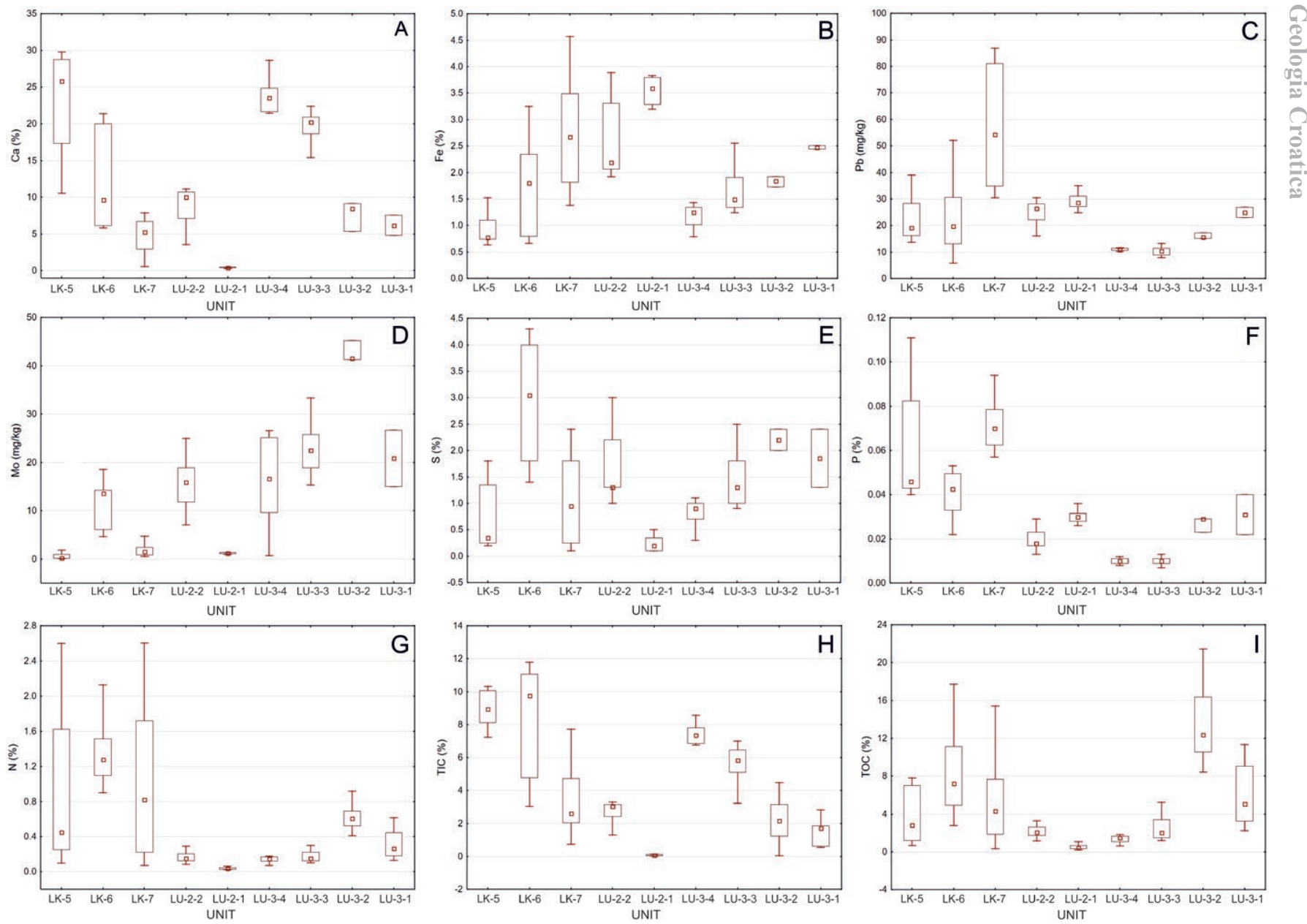

Figure 9. Box and whisker plots of sediment core data. The squares in the each box represent median values. The 25 th and 75 th percentile are the bottom and the top of the each box, respectively. Whisker ends are the non-outlier minimum and maximum values.

distinguished sediment core units from LK-2 and LK-3 cores, nine groups of cored sediments were created to provide the most effective rapport between their geochemical signature and immediate sedimentary environment.

As seen from the scatterplot of variable loadings (Fig. 10), DF1 is highly bipolar separating principally the LK-5 and LK-7 groups from most of the LK-3 sediment core groups (LK-3-2, LK3-3 and LK-3-4) while other groups remain to a great extent poorly differentiated sticking closer to the point of the axis intersection. The rationale for this separation is founded primarily in the negative association between P and Mo. Geochemically it can be understood as the LK-5 and LK-7 cores are relatively enriched in $\mathrm{P}$ and depleted in Mo in comparison to the upper three LK-3 units. The groups positioned in the middle reflect the average composition of all the investigated core units - a "mixed" geochemical signature.

DF2, comprising over $25 \%$ of the total variance of geochemical data is also bipolar and can be interpreted as reflecting a negative correlation between the element suite including $\mathrm{Cu}, \mathrm{Pb}, \mathrm{K}$, $\mathrm{Al}$, Fe against another set of elements led by TIC, Ca, N. This pattern is a geochemical signature dividing the LK-2-1 from LK-6 groups on the basis of the clay/carbonate (inorganic carbon) background. Despite making only a minor contribution to the overall model significance $(6 \%)$, DF3 as a monopolar function clearly highlights the LK-3-1 and LK-3-2 groups based on their affinity with $\mathrm{C} / \mathrm{N}$ with a slight TOC association (Fig. 10).

\section{DISCUSSION}

\subsection{Foraminiferal assemblages and geochemical characterization of the surface sediments from the marine ponds on Cres Island}

Studies of the foraminiferal assemblages or sediment geochemistry in the marginal marine environments along the eastern Adriatic coast have been relatively scarce (MIHELČIĆ et al., 1996; VANIČEK et al., 2000; CUCULIĆ et al., 2009; MLAKAR et al., 2015; FELJA et al., 2015; SHAW et al., 2016; SONDI et al., 2017). The focus of many studies worldwide, including the western coast of the Adriatic Sea, has been determination of the foraminiferal fauna inhabiting these transitional environments (e.g., SERANDREI-BARBERO et al., 1999; CARBONI et al., 2009; KEMP et al., 2013; STÉPHAN et al., 2014; MILKER et al., 2015). Different environmental parameters and sediment geochemistry are considered to be important for foraminiferal distribution (DEBENAY et al., 2001; DEBENAY \& GUILLOU, 2002; FRONTALINI et al., 2011a; FRONTALINI et al., 2013).

The main sediment and water characteristics of the Marinska, Arcij and Podbrajde marine ponds investigated here are shown in Table 7. At the sampling time, water in the Marinska pond was brackish with a temperature above $28^{\circ} \mathrm{C}$ and oxygen saturation of $15.12 \mathrm{mg} / \mathrm{l}$. Sediments in this marine pond are characterized by their high $\mathrm{N}$ and $\mathrm{P}$ contents (Figs. 9F and 9G). A high P concentration in the surface sediments probably occurs due to delay in mineralisation of recently settled organic material (HOLTAN 

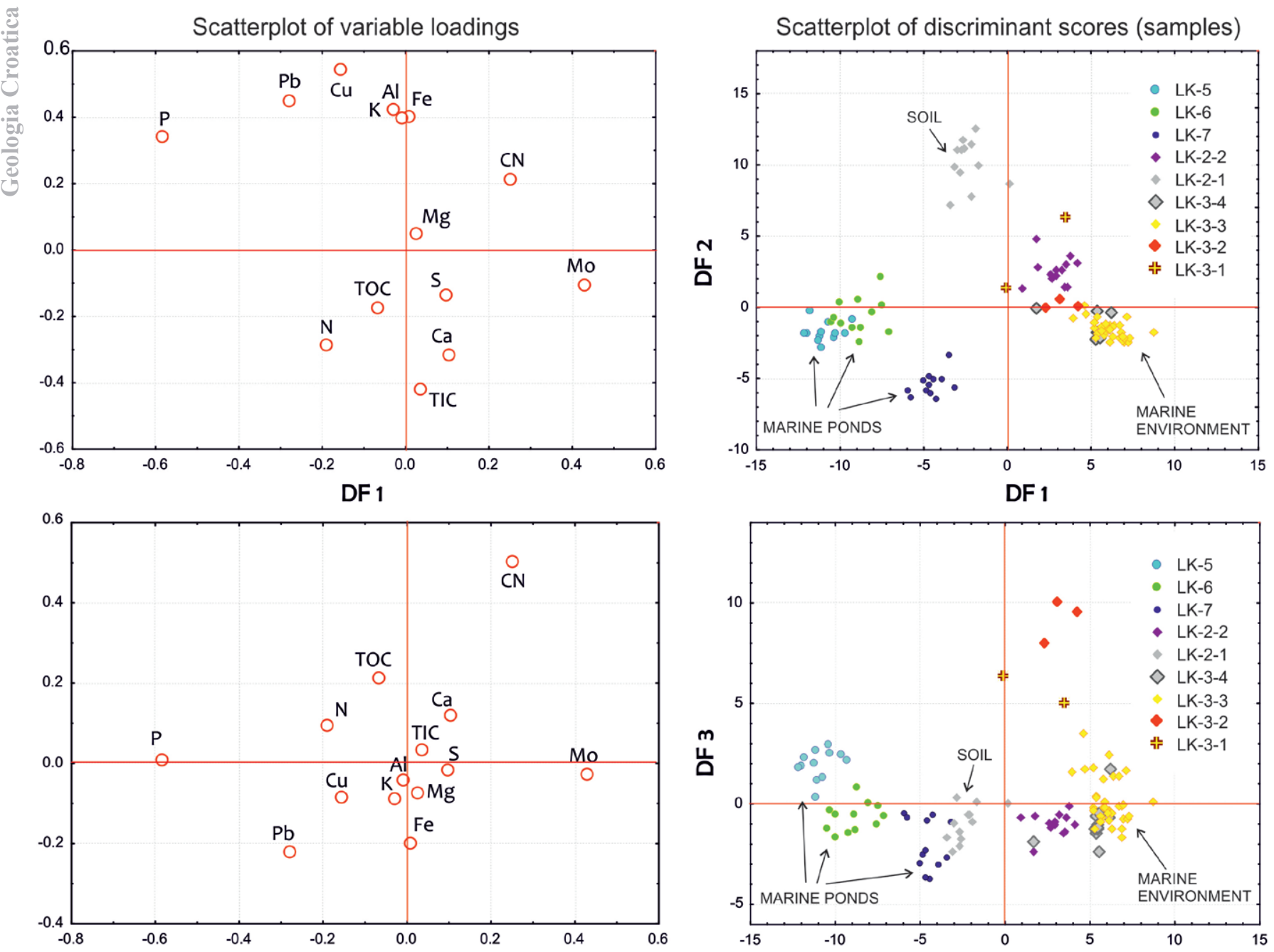

Figure 10. Comparison between variables and groups in the clr-transformed data discriminant function model (DFM): the scatterplots of variable loadings and discriminant scores (samples) in the reduced discriminant space of the first three discriminant functions (DF1-DF2 and DF1-DF3).

et al., 1988). A source of these elements could also be input of bird faeces (guano) into the ponds (BATANERO et al., 2017), considering that the investigated areas are habitats for migratory marsh birds (most commonly mallard- Anas platyrhynchos), as well as woodcock (Scolopax rusticiola) and seagulls (KRALJ, pers.comm.). The mallard and woodcock are also frequently hunted in the area. High nutrient concentrations enabled the development of environmental conditions that facilitated accumulation of organic matter in the sediments (Figs. 9F and 9G). A low $\mathrm{C} / \mathrm{N}$ ratio implies an algal origin of the preserved organic matter (MEYERS, 1994; MEYERS, 2003; LAMB et al., 2006). The TIC also proved to be an important sediment component (Tab. 5, Fig. 9H). The Mo and S concentrations in the Marinska pond sediments are low (Figs. 9D and 10E; Fig. 11A). Preserved Mo is not an indicator of anoxic environmental conditions and can be linked to the input of terrestrial soil material based on the high correlation of Mo with Al (Fig. 11C) (GOLDBERG et al., 1996). Terra rossa topsoils from sites in Dalmatia have a mean concentration of $3 \mathrm{mg} / \mathrm{kg}$ Mo (MIKO et al., 2007).

Only agglutinated taxa typical of intertidal environments are present in the Marinska marine pond. The species H. canariensis and T. inflata predominate, while E. macrescens and $M$. fusca are significantly less abundant. Different species of the genus Haplophragmoides have already been recognized in the Adriatic Sea (CIMERMAN \& LANGER, 1991; SERANDREI BARBERO et al., 2004; SHAW et al., 2016), while T. inflata appears to be frequent in the marginal marine environments along the Croatian coast of the Adriatic Sea (FELJA et al., 2015; SHAW et al., 2016). Generally, this species has been reported from many restricted, brackish water environments in the Mediterranean region (SERANDREI BARBERO et al., 1999; SERANDREI BARBERO et al., 2004; DEBENAY \& GUILLOU, 2002; FRONTALINI et

Table 7. The main sediment and water characteristics of the Marinska, Arcij and Podbrajde marine ponds.

\begin{tabular}{lccccc}
\hline MARINE POND & WATER & WATER COLUMN DEPTH & NUTRIENTS AMOUNT & ORGANIC MATTER & Mo \\
\hline Marinska & marine & deeper (no drying out) & high & high & terrestrial \\
Arcij & brackish & very shallow & high & high & Ammonia tepida \\
Podbrajde & marine & $\begin{array}{c}\text { shallow (drying out phases } \\
\text { possible only at the } \\
\text { margins of the pond) }\end{array}$ & high & high & terrestrial
\end{tabular}


al., 2011a) and elsewhere (LIDZ \& ROSE, 1989; SEN GUPTA et al., 2009). Recognized agglutinated foraminiferal fauna typically occur in the zone between mean sea level and mean high water level in salt-marsh areas of the Adriatic Sea (SERANDREI BARBERO et al., 1999; SHAW et al., 2016), indicating that in the investigated environment tidal influence is important. The Marinska marine pond is located $50 \mathrm{~m}$ from the sea and the possible tidal influence could be through karst features. Although foraminiferal species richness in the Marinska pond is low, recognized species seem to be well adapted to the restricted environmental conditions due to their abundance. However, a significant number of damaged tests were also observed, possibly indicating conditions unsuitable for their preservation (Plate 1). DEBENAY (2001) observed the presence of T. inflata in marshes with variable salinity and TOC content, while DEBENAY \& GUILLOU (2002) reported the preference of this species for muddy sediments in microtidal Mediterranean environments. However, our results proved that although TOC content was high, this species occurred in the brackish water environment with high percentages of sand (up to $75 \%$ ). Grain-size distribution, as well as the mineralogical composition of the sediment, has important implications for agglutinated taxa (ALLEN et al., 1999; ARMYNOT DU CHÂTELET et al., 2008; ARMYNOT DU CHÂTELET et al., 2013). SEM-EDS analysis showed that identified agglutinated foraminifera from the Marinska pond used variable mineral grains for building their tests (quartz, amphibole, mica and feldspars) (Fig. 8). Some mineral grains were not recognized in the bulk mineralogical composition of the sediment, probably due to
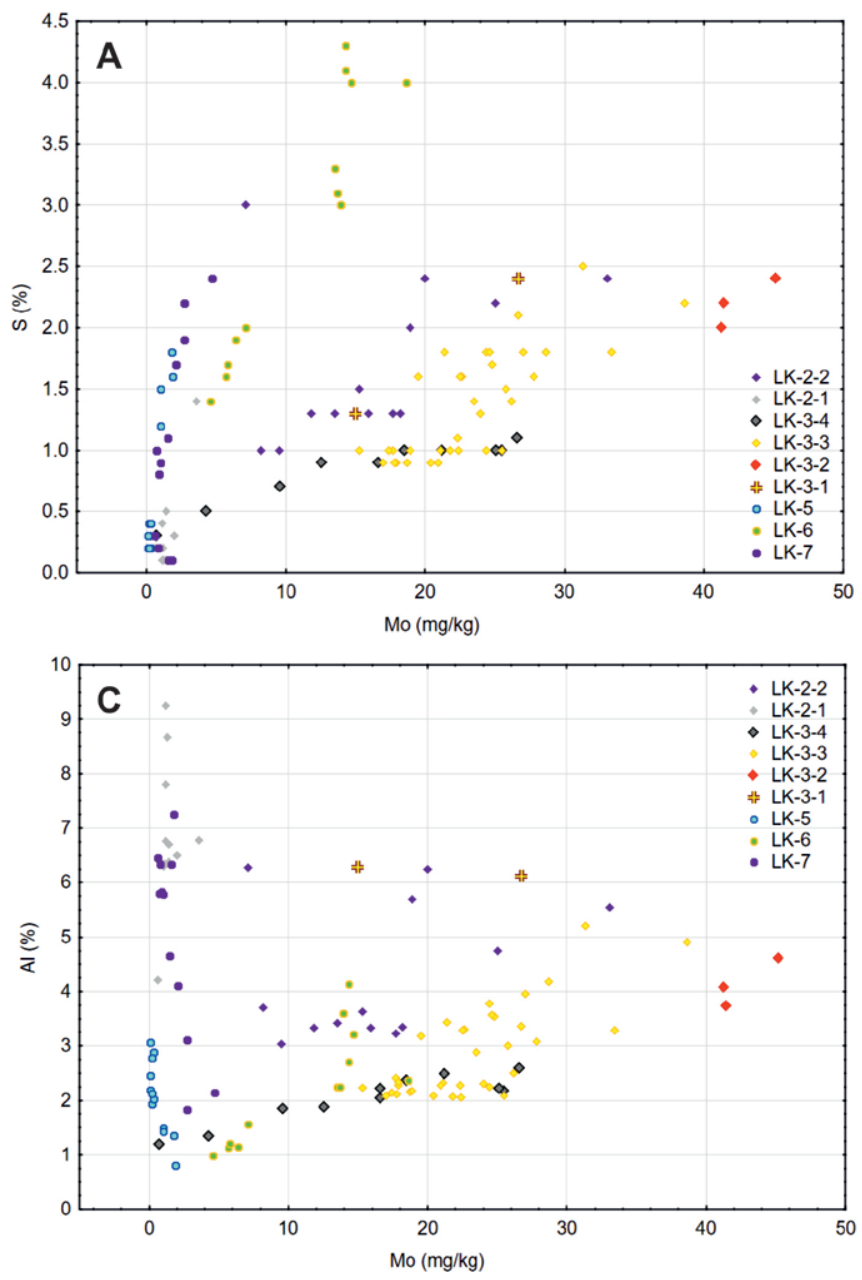

their low abundances. This indicates the preference of agglutinated taxa for specific mineral grains. ALLEN et al. (1999), ARMYNOT DU CHÂTELET et al. (2008), MAKLED \& LANGER (2010) and ARMYNOT DU CHÂTELET et al. (2013) in their studies have determined that some species preferentially select certain mineral grains from their surroundings, while significant differences among species also exist.

Mineral analysis also revealed the presence of the clay mineral sepiolite, usually found in restricted environments, ponds or shallow brackish lakes with high evaporation rates (ORDÓÑEZ et al., 1991; VELDE, 1995; MEUNIER, 2003; BUSTILLO \& ALONSO-ZARZA, 2007). Direct precipitation of sepiolite occurs from solutions with abundant Mg and Si (MAYAYO et al., 1998) in the high $\mathrm{pH}$ environments (STARKEY \& BLACKMON, 1984). BUSTILLO \& ALONSO-ZARZA (2007) indicate that sepiolite can be formed by the transformation of illites or smectites in a vadose alkaline environment with $\mathrm{Mg}$ rich groundwater originating from dolomitic aquifers. The presence of sepiolite implies the significant impact of climate conditions (precipitation, evaporation) on the water level in the Marinska pond that has been developed in a generally dolomitic lithological setting. Seasonal climatic variability with periods of high evaporation from the marine pond, could have enabled the development of environmental conditions that favoured the precipitation of sepiolite in the Marinska pond.

Conductivity $\left(\mathrm{E}_{\mathrm{c}}\right)$ and $\mathrm{O}_{2}$ measurements in the water in the Arcij marine pond indicate the existence of an oxygenated en-
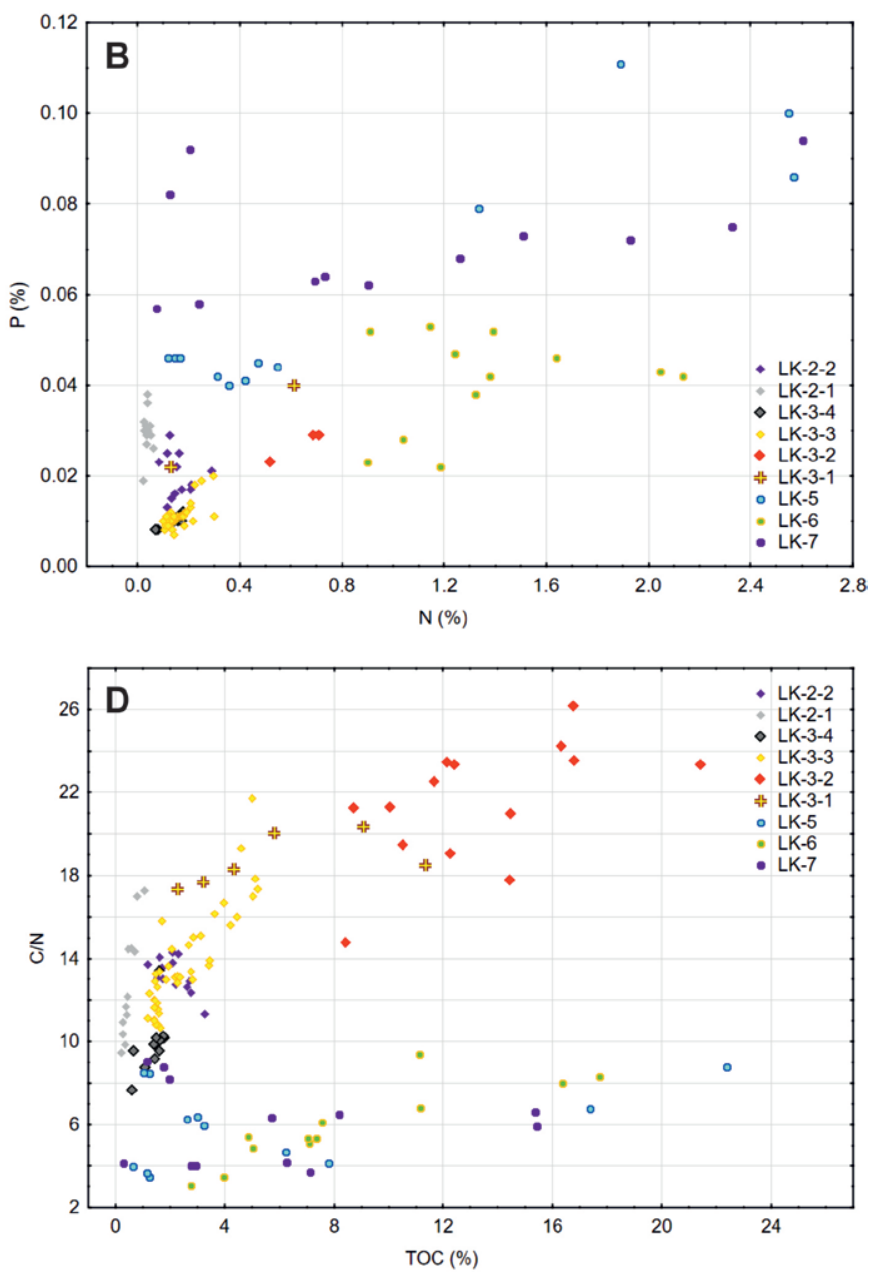

Figure 11. Scatterplots of A) Mo (mg/kg) against S (\%) B) N (\%) against P (\%), C) Mo (mg/kg) against Al (\%), D) TOC (\%) against C/N. 
closed marine environment. Regardless of the larger distance of this marine pond from the sea $(92 \mathrm{~m})$, a stronger seepage of sea water probably occurs due to the well-developed karstification and fissures system of the ridge separating the pond from the sea. A silty surface sediment is enriched with TOC (7.58\%) and TIC (8.29\%), while the organic matter is predominantly of algal origin (C/N<12; MEYERS, 1994; MEYERS, 2003; LAMB et al., 2006). Similarly to the Marinska marine pond, the primary productivity indicators ( $\mathrm{N}$ and $\mathrm{P}$ ) are abundant. The Mo and $\mathrm{S}$ concentrations in the sediment are higher in comparison to the other marine ponds, causing reducing sediment conditions and thus further facilitating the preservation of organic matter. In the Arcij pond, the source of Mo could be different to that of the Marinska pond (Fig. 11C). In many papers (PEDERSEN, 1989; CRUSIUS et al., 1996; CALVERT \& PEDERSEN, 1993; ALGEO \& LYONS, 2006; SCHOLZ et al., 2017) the application of Mo as an indicator of redox conditions was emphasized. It is considered that Mo precipitation often occurs in anoxic and organic matterrich silled basins (ALGEO \& LYONS, 2006). We suggest enrichment with Mo in the Arcij pond is a consequence of stagnant bottom water and reducing conditions. The $\mathrm{S}$ concentrations are also high (Fig. 9E). The presence of hydrogen sulfide $\left(\mathrm{H}_{2} \mathrm{~S}\right)$ seems to be important for the uptake of Mo, especially in shallow water environments and non-silled basins (PEDERSEN, 1989; ALGEO \& LYONS, 2006; SCHOLZ et al., 2017). This can be applicable to the Arcij pond (Fig. 11A), where pyrite is formed. Established environmental conditions do not seem to be a limiting factor for the presence of foraminifera. The most common species occurring in the Arcij pond is $A$. tepida, with a relative abundance of almost $97 \%$ (Tab. 5). This species has been identified in numerous shallow water marine environments, restricted marginal marine environments (lagoons, estuaries, salt-marshes) and inland saline pools due to its tolerance to normal, brackish and hypersaline water conditions (JORISSEN, 1988; DEBENAY, 1990; ALMOGI-LABIN et al., 1992; DEBENAY et al., 2001; DEBENAY \& GUILLOU, 2002; DEBENAY \& GUIRAL, 2006; MURRAY, 2006; VIDOVIĆ, 2010; FRONTALINI et al., 2011a). In previously conducted research, the ability of $A$. tepida to tolerate environmental stress has been emphasized (ALMOGI-LABIN et al., 1992; DEBENAY et al., 2001; DEBENAY \& GUILLOU, 2002). Abundance of this species in the organic matter-rich Arcij marine pond further supports this. A significant number of living specimens was observed, implying their adaptation to the environmental conditions in the investigated marine pond. Ammonia specimens with abnormal test morphology have also been recognized, further indicating the existence of environmental stress or possibly genetic or mechanical influences (ALMOGI-LABIN et al., 1992). A relatively small number of living deformed specimens (6 specimens; Tab. 4) was observed in the analysed sample, which does not facilitate explanation of the dominant factor causing the stress in the Arcij pond. Oxygen deficiency and nutrient abundance in the sediment could be possible factors.

In the Podbrajde marine pond, located $136 \mathrm{~m}$ from the sea, only 7 foraminifera specimens have been found in the analysed core top (Tab. 5). This general absence of abundant foraminiferal assemblages, in comparison to the other marine ponds, could be explained by the greater distance of this environment from the sea and a more prominent disconnection from a direct marine influence. However, measured $\mathrm{E}_{\mathrm{c}}$ values indicate the existence of normal marine conditions which makes it difficult to explain the lack of rich foraminiferal assemblages. Geochemical sediment analysis revealed similar conditions to those in the previously de- scribed marine ponds, especially the Marinska pond, with nutrient enrichment and an algal source of organic matter (MEYERS, 1994; MEYERS, 2003; LAMB et al., 2006) (Tab. 4). The Mo in the Podbrajde marine pond also seems to be of terrestrial origin (Fig. 11C) (GOLDBERG et al., 1996). The only notable difference in the geochemical record, in comparison to the previously described ponds, is the high $\mathrm{Pb}$ concentration (Fig. 9C). Generally, it is considered that elevated concentrations of $\mathrm{Cd}, \mathrm{Pb}, \mathrm{Cu}$ and $\mathrm{Zn}$ are a consequence of anthropogenic activities (CLARK, 2001). Sediment enrichment with $\mathrm{Pb}$ could also occur due to the spent shot during hunting (MATEO, 2009; MIGANI et al., 2015). The results from ROMANO et al. (2016) imply that metallic $\mathrm{Pb}$ from spent shot during hunting is oxidized and dissolved in wetlands leading to its mobilization and redistribution in wetland sediments. MIGANI et al. (2015) came to similar conclusions for lagoons on the northern Adriatic coast. SUOKHRIE et al. (2017) provided an overview of studies related to foraminifera exposed to different pollutants including heavy metals. Most studies indicate that high $\mathrm{Pb}$ concentrations in marine sediments result in low diversity of fauna and the predominance of opportunistic species, as well as an increase in the abnormalities of foraminiferal tests. FRONTALINI et al. (2015) exposed Ammonia parkinsoniana specimens, cultured in mesocosms, to various concentrations of $\mathrm{Pb}$ in sediments. Specimens showed cytological modifications that might be related to pollutant-induced stress. The elevated concentrations of $\mathrm{Pb}$ could possibly inhibit the development of abundant foraminiferal assemblages within the studied coastal marine pond. If the concentrations of $\mathrm{Pb}$ in the studied marine pond have a major influence on the lack of an abundant foraminiferal fauna, then correlation of modern environments with those of the past (pre-flooding) could be somewhat limited.

The presence of foraminifera in environments isolated from a direct marine influence has been attributed to transport by birds (DEBENAY, 1990; ALMOGI-LABIN et al., 1992). The same transport mechanism can explain the foraminiferal presence in the investigated marine ponds. However, seepage through the karstified underground is probably the dominant factor contributing to the foraminiferal dispersal. Sirocco and bora winds, that are common along the eastern Adriatic coast (PANDŽIĆ \& LIKSO, 2005; SIGNELL et al., 2010), could also introduce marine fauna into the ponds.

\subsection{Palaeo-marine ponds and the palaeoenvironmen- tal evolution of the Jaz and Sonte embayments}

Differentiated units from sediment cores collected in the submerged dolines in the Jaz and Sonte embayments, correspond to different Holocene palaeoenvironments. Foraminiferal analysis was conducted only in intervals were the existence of a transitional terrestrial to marine environment was assumed. Furthermore, recognized foraminiferal fauna and geochemical data were compared to the data from the Marinska, Podbrajde and Arcij marine ponds in order to possibly detect Holocene analogs of the marginal marine environments that nowadays exist in the coastal zone of Cres Island. Foraminiferal assemblages from the core tops collected in the embayments were also investigated in order to compare typical shallow marine assemblages in the area with the taxa present downcore and in the marine ponds. A similar type of research has already been conducted in the Adriatic Sea in the Venice lagoon (SERANDREI BARBERO et al., 2004).

Two distinct intervals were recognized in the sediment core LK-2 collected in the Jaz embayment. The first interval (unit 

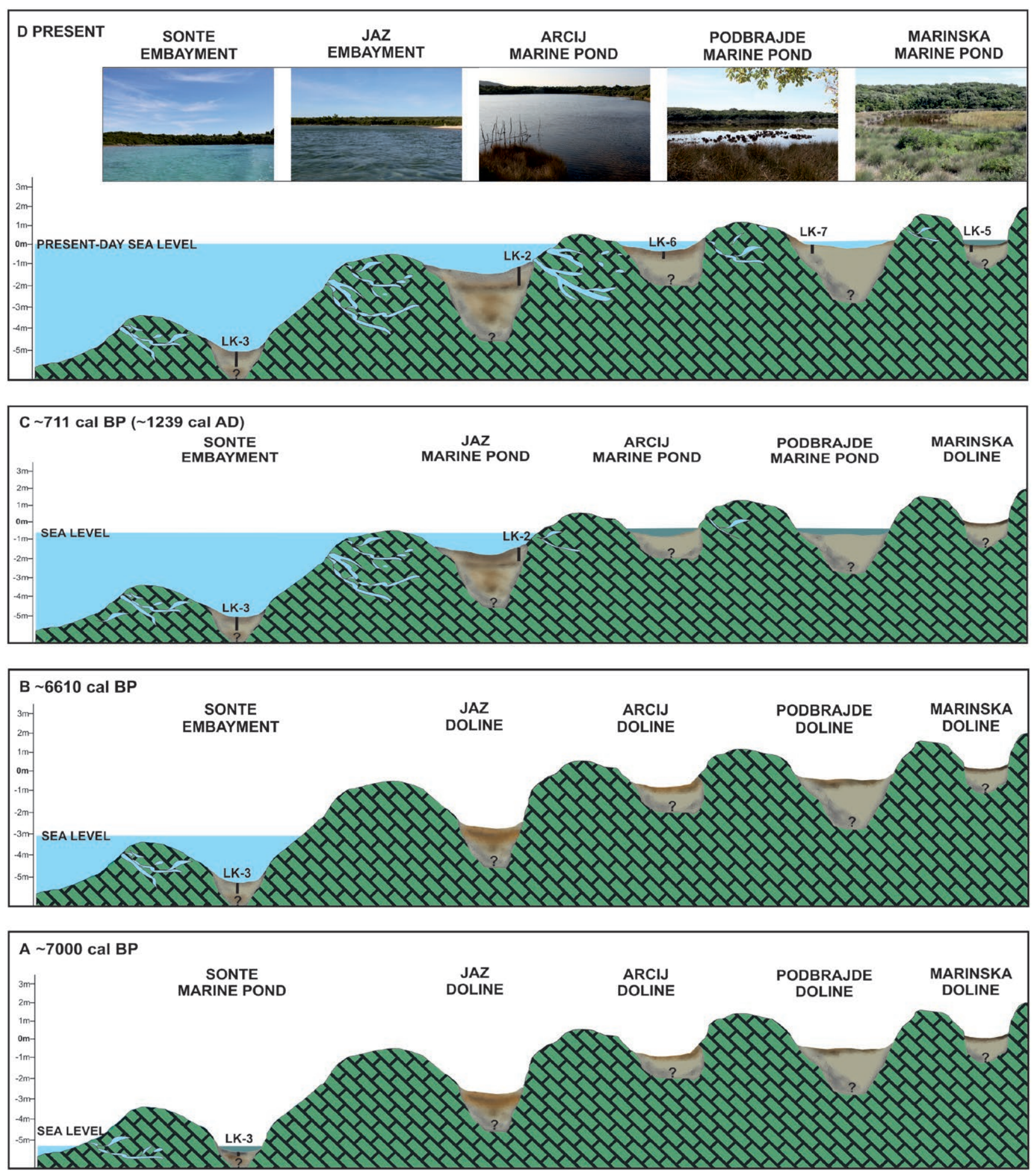

Figure 12. Schematic drawing of the palaeoenvironmental development of the Marinska, Arcij and Podbrajde marine ponds and the Jaz and Sonte embayments at A) approximately 7000 cal BP, B) approximately 6610 cal BP, C) approximately 711 cal BP, D) present.

LK-2-1), comprising the basal part of the core, implies soil accumulation with high metal concentrations ( $\mathrm{Al}, \mathrm{Fe}, \mathrm{K}, \mathrm{Cu}, \mathrm{Pb}$ ) (Fig. $10)$ in the karst depression. The geochemical and mineralogical signature is typical for terra rossa soils developed in carbonate terrains (DURN et al., 1999; MIKO et al., 2001). Foraminiferal absence is a prominent characteristic of this environment, which further supports the palaeoenvironmental interpretation (Figs. 12A and 12B). The abrupt change in the core data (unit LK-2-2) (Fig. 5) was observed at approximately $711 \mathrm{cal}$ BP evidencing an important environmental transition. A significant rise in the Mo and S concentrations (Fig. 5) probably indicates establishment of an oxygen depleted restricted water body (PEDERSEN, 1989; CRUSIUS et al., 1996; CALVERT \& PEDERSEN, 1993; ALGEO \& LYONS, 2006; SCHOLZ et al., 2017). The high TOC content supports this, while also implying increased primary productivity (Fig. 5). However, it seems that this environment was not as productive as the present-day marine ponds on Cres Island or these differences could be a consequence of diagenesis (Figs. 9F 
and 9G; Fig. 11B). The $\mathrm{C} / \mathrm{N}$ ratio is indicative of a mixed terrestrial and algal organic matter provenance, which also differs in comparison to the present-day marine ponds (Fig. 11D) (MEYERS, 1994; MEYERS, 2003; LAMB et al., 2006). At this transition in core LK-2, a more detailed analysis of foraminiferal assemblages was conducted (Fig. 3). The presence of foraminifera proved that the marine influence in the Jaz embayment begun at approximately 711 cal BP. A poorly diversified assemblage was determined, predominantly composed of numerous specimens of foraminifera typical of the brackish or shallow marine conditions usually established in the marginal marine environments ( $A$. tepida, A. parkinsoniana and $H$. depressula) (MURRAY, 2006; VANIČEK et al., 2000). Differentiated species seem to be well adapted to the reduced oxygen availability in the sediment. The susceptibility of $A$. tepida and the genus Haynesina to environmental stress has been previously determined (ALMOGI-LABIN et al., 1992; DEBENAY et al., 2000; DEBENAY et al., 2001; DEBENAY \& GUILLOU, 2002; VIDOVIĆ et al., 2009). However, A. parkinsoniana is not considered to be a stress-tolerant species (VIDOVIĆ et al., 2014). Cluster analysis enabled the identification of different core intervals characterized by similar assemblages (Fig. 7). We consider the similarity of samples from the transitional zone of the Jaz core and samples from the Arcij marine pond as evidence of the establishment of similar environments. Therefore, a palaeo-marine pond with a strong marine influence, analogous to the present-day Arcij marine pond, developed at approximately $711 \mathrm{cal}$ BP when the sea-water level approached the depth of the sill at $-0.5 \mathrm{~m}$ (Fig. 12C). However, statistical analysis of geochemical data does not fully support this interpretation (Fig. 10), possibly due to differences in the geological setting of the Arcij marine pond and the Jaz embayment where siliciclastic input is more prominent (Fig. 10). It is probable that this environment existed for a very short time before it was flooded with sea-water and the Jaz embayment was formed.

The LK-2 core top analysis implies the existence of an oxygen depleted sedimentary environment in the present-day Jaz embayment (Fig. 12D). Geochemical analysis of the surface sediment revealed high Mo concentrations $(8.2 \mathrm{mg} / \mathrm{kg})$ and lower TOC and TIC contents in comparison to the investigated inland marine ponds. A significant difference is in the nutrient availability and source of organic matter, with a high $\mathrm{C} / \mathrm{N}$ ratio indicating mixed algal and terrestrial organic matter origin (MEYERS, 1994; MEYERS, 2003; LAMB et al., 2006). The core top sample proved to contain a highly diversified foraminiferal assemblage in comparison to present-day marine ponds, with 32 recognized species. The most common species A. tepida, A. parkinsoniana, Ammonia sp., B. striatula, E. margaritaceum, E. translucens and $H$. depressula are typical for organic matter enriched marine environments along the eastern Adriatic coast (VIDOVIĆ, 2010).

Palaeoenvironmental development of the Sonte embayment encompasses a longer time span (Figs. 12A and 12D). The present-day Sonte embayment has a maximum depth of $5 \mathrm{~m}$, while the sill depth is $3 \mathrm{~m}$. Accumulation of the sediment sequence was possible due to the morphology of this depression. Analysed samples from the lowermost part of the core exhibit similarity in geochemical and mineralogical composition to the basal part of the LK-2 core (Fig. 10) and indicate terrestrial soil (DURN et al., 1999; MIKO et al., 2001). Within this interval (unit LK-3-1) poorly preserved specimens of foraminifera occur in low numbers, making it difficult to interpret an established environment. The rare specimens were probably deposited due to transport by waves and/or winds as a consequence of the gradual Mid-Holocene sea level rise on the seaward side of the karstified sill/barrier.

Further up-core (unit LK-3-2), a significant rise in the TOC content was observed (Fig. 9I). We suggest development of a stagnant water body at approximately $8000 \mathrm{cal}$ BP (according to the age-depth model) on previously formed soil. Increased nutrient availability could facilitate organic matter production, similar to the Marinska, Podbrajde and Arcij marine ponds (Fig. 11B). However, most of the organic matter has a terrestrial source possibly indicating input from the land under a different climatic setting or the enhanced growth of terrestrial plants (Fig. 11D). This interval could be correlated with the Holocene pluvial period recognized in the Adriatic Sea (WUNSAM et al., 1999; SCHMIDT et al., 2001) and in the lacustrine sediments from karst poljes and lakes located along the eastern Adriatic coast (SCHMIDT et al., 2000; BALBO et al., 2006; ILIJANIĆ et al., 2018).

The established environment was probably poorly oxygenated, which enabled the preservation of organic matter. Relatively high values and covariation of Mo and TOC corroborates this conclusion (CRUSIUS et al., 1996; CALVERT \& PEDERSEN, 1993; ALGEO \& LYONS, 2006; SCHOLZ et al., 2017). The Mo concentrations are significantly higher in comparison to the present-day concentrations in the marine ponds (Fig. 9D), indicating low oxygen abundance due to the development of a restricted environment with water stratification. The $\mathrm{S}$ concentrations are high and similar to those in the Marinska, Arcij and Podbrajde marine ponds on Cres Island, further supporting the development of a restricted and oxygen poor water body (Fig. 9E, Fig. 11A). Dominant taxa, A. tepida, Ammonia beccarii, H. depressula, Asterigerinata mamilla, Porosononion sp., Elphidium fichtelianum and $C$. gerthi imply the existence of shallow marine to possibly slightly brackish water environmental conditions (MURRAY, 2006). A. tepida and A. beccarii have been frequently observed in the sediments along the eastern coast of the Adriatic Sea with high P and TOC content (VIDOVIĆ et al., 2014). The presence of the genus Haynesina can also be correlated with the enrichment of TOC in sediment (DEBENAY et al., 2001; VIDOVIĆ et al., 2009; VIDOVIĆ et al., 2014). Statistical analysis demonstrated the highest similarity of the foraminiferal assemblages from this unit with the present-day Arcij marine pond and previously described transitional zone in the core from the Jaz embayment. This suggests development of a palaeo-marine pond with normal marine water (Fig. 12A). However, such similarity was not observed in the statistically analysed geochemical data, where this unit correlates well with the topmost part of the Jaz embayment core therefore implying similarity of these environments (Fig. 10). Micropalaeontological data and geochemistry therefore suggest different palaeoenvironments, but generally provide evidence of a significant marine influence during the deposition of sediments from unit LK-3-2.

At 6610 cal BP (unit LK-3-3) a decrease in TOC content and Mo concentrations, followed by an increase in TIC indicate major environmental change in comparison to the previously described unit (Fig. 6). Carbonates become a more important sediment component (Fig. 9H, Fig. 10). Surface sediments deposited along the present-day eastern Adriatic coast are also enriched in carbonates (PIKELJ et al., 2009; PIKELJ, 2010). The newly formed environment was nutrient-deprived, which prevented organic matter accumulation (Fig. 11B). However, preserved organic matter has mixed algal-terrestrial origin (Tab. 4, Fig. 6) (MEYERS, 1994; MEYERS, 2003; LAMB et al., 2006). Foraminiferal assemblages became highly diversified and dominated by $A$. tep- 
ida, E. translucens, A. beccarii, Ammonia sp., C. gerthi, E. fichtelianum, Porosononion sp.1, Q. parvula and Q. seminula specimens. Dominant species are similar to the previously described interval. However, species richness and diversity increased significantly. Increases in the relative abundance of miliolids were also observed. This can suggest the existence of an enclosed environment (DEBENAY \& GUILLOU, 2002; LIDZ \& ROSE, 1989) or hypersaline lagoon (DEBENAY et al., 2001). Genus Quinqueloculina is abundant in the Mljet Lakes (ĆOSO-VIĆ et al., 2016), while DEBENAY \& GUILLOU (2002) reported the association of $A$. tepida and $Q$. seminula in the subtidal areas, marshes and mudflats with developed seaweeds. According to VIDOVIĆ (2010) miliolids are common in marine environments along the Croatian coast of the Adriatic Sea. The determined assemblage, predominantly comprising the genera Ammonia, Elphidium, Haynesina and Quinqeloculina, can be compared to the previously recognized Haynesina-Ammonia assemblage from the shallow marine environments in the Soline embayment and Nin Bay (VIDOVIĆ, 2010). Cluster analysis grouped samples from this unit into the same subcluster as the surface sample from the Jaz embayment where shallow marine environmental conditions prevail today. Statistical analysis of the geochemical data also indicated this similarity. It is our interpretation that at $6610 \mathrm{cal}$ BP a marine influence became more prominent in the Sonte embayment, possibly with the sea water spilling over the sill (Fig. $12 \mathrm{~B})$. This is in general agreement with the published global and regional sea level curves (CORREGGIARI et al., 1996; WAELBROEK et al., 2002; LAMBECK et al., 2014; VACCHI et al., 2016).

The topmost part of the core (unit LK-3-4) can be geochemically distinguished from the previously described core intervals (Fig. 6). This is probably indicative of the establishment of a more permanent, fully marine environment (Fig. 12D). A highly diversified foraminiferal assemblage consisting of 41 recognized species was determined in the LK-3 core top. The dominant Sonte embayment foraminiferal fauna $(G$. praegeri, $H$. depressula, $H$. germanica, A. tepida, A. mamilla and Bolivina pseudoplicata) is typical for littoral environments in the Adriatic Sea (JORISSEN, 1988; VIDOVIĆ, 2010).

In the investigated embayment, the determined surface assemblage is present in the sand dominated sediment, with low Mo and S concentrations, low TOC content and high TIC values (Fig. 6). However, although the sediment is oxygenated, measured oxygen concentrations in the water were the lowest among all the investigated environments (Tab. 2), probably due to the greater depth of this environment. Primary productivity in the Sonte embayment is limited due to the nutrient deficiency (Fig. 11B) and therefore organic matter content is low (Fig. 9I). Cluster analysis grouped foraminifera from this sample into the same subcluster as the previously described marine samples (Fig. 7). Statistical analysis of the geochemical data indicated a similarity to other marine units from the LK-3 and LK-2 cores (Fig. 10).

\section{CONCLUSIONS}

Marine ponds have been developed in the coastal karst dolines along Cres Island. Sediments preserved in the Marinska, Arcij and Podbrajde marine ponds revealed important micropalaeontological and geochemical data that was used to characterize these marginal marine environments. Detailed analysis of sediment cores from the Jaz and Sonte embayments, developed in now submerged dolines, revealed the complex palaeoenvironmental evolution of the investigated area. The downcore micro- palaeontological and geochemical data enabled detection of the Holocene palaeo-marine ponds. We suggest the development of a palaeo-marine pond, similar to the present-day Arcij pond, at approximately $711 \mathrm{cal}$ BP in the Jaz embayment. A palaeo-marine pond in the Sonte embayment existed up to $6610 \mathrm{cal}$ BP. These palaeo-marine ponds were flooded during the Holocene sea level rise, when the marine environment was established. Therefore, recognition of different environments developed in the karst dolines, located in the coastal zone of Cres Island, was possible. The research of the present-day marginal marine environments along the eastern Adriatic coast could prove to be valuable for palaeoenvironmental studies and especially Holocene sea level change research.

\section{ACKNOWLEDGEMENT}

This research was funded by the Croatian Science Foundation (HRZZ) through the interdisciplinary project „Lost Lake Landscapes of the Eastern Adriatic Shelf“ (LoLADRIA; project no. 9419). The authors would like to thank Hrvoje BURIĆ and Edin BADNJEVIĆ for their help during the fieldwork campaign and Ana-Maria HESKI and Helena ĆUĆUZOVIĆ for performing grain-size analysis. We would also like to thank Editor Mladen JURAČIĆ and two anonymous reviewers whose comments significantly improved the manuscript. Furthermore, we thank the „MOPP-MEDFLOOD“ community and INQUA for financing attendances on their workshops and field excursions where some results of this study were presented and discussed.

\section{REFERENCES}

ALGEO, T.J. \& LYONS, T.W. (2006): Mo-total organic carbon covariation in modern anoxic marine environments: Implications for analysis of paleoredox and paleohydrographic conditions.- Paleoceanography, 21/1, PA1016. doi:10.1029/ 2004PA001112

ALLEN, K., ROBERTS, S. \& MURRAY, J.W. (1999): Marginal marine agglutinated foraminifera: Affinities for mineral phases.- J. Micropalaeontology, 18/2, 183-191. doi: $10.1144 / \mathrm{jm} .18 .2 .183$

ALMOGI-LABIN, A., PERELIS-GROSSOVICZ, L. \& RAAB, M. (1992): Living Ammonia from a hypersaline inland pool, Dead Sea area, Israel.- J. Foraminifer. Res., 22/3, 257-266. doi: 10.2113/gsjfr.22.3.257

ALVE, E. \& MURRAY, J.W. (1999): Marginal marine environments of the Skagerrak and Kattegat: A baseline study of living (stained) benthic foraminiferal ecology.Palaeogeogr. Palaeoclimatol. Palaeoecol., 146, 171-193. doi: 10.1016/S0031-0182 (98)00131-X

ANADÓN, P., GLIOZZI, E. \& MAZZINI, I. (2002): Paleoenvironmental reconstruction of marginal marine environments from combined paleoecological and geochemical analyses on ostracods.- Geophys. Monogr. Ser., 131, 227-247. doi: 10.1029/ $131 \mathrm{GM} 12$

ARMYNOT DU CHÂTELET, E., RECOURT, P. \& CHOPIN, V. (2008): Mineralogy of agglutinated benthic foraminifera; implications for paleo-environmental reconstructions.- Bull. la Soc. Geol. Fr., 179/6, 583-592. doi: 10.2113/gssgfbull.179.6.583

ARMYNOT DU CHÂTELET, E., BOUT-ROUMAZEILLES, V., COCCIONI, R., FRONTALINI, F., GUILLOT, F., KAMINSKI, M.A., RECOURT, P., RIBOULLEAU, A., TRENTSAUX, A., TRIBOVILLARD, N. \& VENTALON, S. (2013): Environmental control on shell structure and composition of agglutinated foraminifera along a proximal-distal transect in the Marmara Sea.- Mar. Geol., 335, 114 128. doi: 10.1016/j.margeo.2012.10.013

BALBO, A.L., ANDRIČ, M., RUBINIĆ, J., MOSCARIELLO, A. \& MIRACLE, P.T. (2006): Palaeoenvironmental and archaeological implications of a sediment core from Polje Čepić, Istria, Croatia.- Geol. Croat., 59/2, 109-124.

BATANERO, G.L., LEÓN-PALMERO, E., LI, L., GREEN, A.J., RENDÓN-MARTOS, M., SUTTLE, C.A. \& RECHE, I. (2017): Flamingos and drought as drivers of nutrients and microbial dynamics in a saline lake.- Scientific Rep., 7/1, 1-13. doi: 10.1038/s41598-017-12462-9

BENAC, Č. \& DURN, G. (1997): Terra rossa in the Kvarner Area: Geomorphological conditions of formation.-Acta Geographica Croatica, 32/1, 7-19.

BENAC, Č. \& JURAČIĆ, M. (1998): Geomorphological indicators of sea level changes during Upper Pleistocene (Würm) and Holocene in the Kvarner Region (NE Adriatic Sea).- Acta Geographica Croatica, 33, $27-45$. 
BIANCHI, N., FORTINO, S., LEONZIO, C. \& ANCORA, S (2011): Ecotoxicological study on lead shot from hunting in the Padule di Fucecchio marsh (Tuscany, Italy).Chem. Ecol., 27, 153-166. doi: 10.1080/02757540.2011.625941

BENJAMIN, J., ROVERE, A., FONTANA, A., FURLANI, S., VACCHI, M., INGLIS, R.H., GALILI, E., ANTONIOLI, F., SIVAN, D., MIKO, S., MOURTZAS, N., FELJA, I., MEREDITH-WILLIAMS, M., GOODMAN-TCHERNOV, B., KOLAITI, E., ANZIDEI, M. \& GEHRELS, R. (2017): Late Quaternary sea level changes and early human societies in the central and eastern Mediterranean Basin: An interdisciplinary review.- Quat. Int., 449, 29-57. doi: 10.1016/j.quaint.2017.06.025

BLOTT, S.J. \& PYE, K. (2001): Gradistat: A Grain Size Distribution and Statistics Package for the Analysis of Unconsolidated Sediments.-Earth Surf. Process Landforms, 26, 1237-1248. doi: 10.1002/esp.261

BOLTOVSKOY, E. \& LENA, H. (1971): The foraminifera (except family Allogromiidae) which dwell in fresh water--J. Foraminifer Res., 1, 71-76. doi: 10.2113/gsjfr.1.2.71

BORGHESI, F. (2016): Environmental pollution and hunting: exposure of birds to metals in their trophic areas, and of humans to lead in game birds.- PhD Thesis, University of Bologna, $217 \mathrm{p}$

BUSTILLO, M.A. \& ALONSO-ZARZA, A.M. (2007): Overlapping of pedogenesis and meteoric diagenesis in distal alluvial and shallow lacustrine deposits in the Madrid Miocene Basin, Spain.- Sedimentary Geology, 198/3-4, 255-271. doi: 10.1016/j. sedgeo.2006.12.006

CALVERT, S.E. \& PEDERSEN, T.F. (1993): Geochemistry of Recent oxic and anoxic marine sediments: Implications for the geological record.- Mar Geol., 113, 67-88. doi: 10.1016/0025-3227(93)90150-T

CANN, J.H. \& de DEKKER, P. (1981): Fossil Quaternary and living foraminifera from athalassic (non-marine) saline lakes, Southern.- Journal of Paleontology, 55/3, 660670.

CARBONI, M.G., SUCCI, M.C., BERGAMIN, L., DI BELLA, L., FREZZA, V. \& LANDINI, B. (2009): Benthic foraminifera from two coastal lakes of southern Latium (Italy). Preliminary evaluation of environmental quality.- Mar. Pollut. Bull., 59, 268-280. doi: 10.1016/j.marpolbul.2009.08.010

CIMERMAN, F. \& LANGER, M.R. (1991): Mediterranean foraminifera.- Razred za naravoslovne vede, classis IV: historia naturalis, opera 30 . Slovenska akademija, Ljubljana, str. $118+93$ pls.

CLARK, R.B. (2001): Marine Pollution, 5th edition.- Oxford Univ. Press, Oxford, UK, $248 \mathrm{p}$.

CORREGGIARI, A., ROVERI, M. \& TRINCARDI, F. (1996): Late Pleistocene and Holocene Evolution of the North Adriatic Sea.- II Quaternario, Italian Journal of Quaternary Sciences, 9, 697-704

CRUSIUS, J., CALVERT, S., PEDERSEN, T. \& SAGE, D. (1996): Rhenium and molybdenum enrichments in sediments as indicators of oxic, suboxic and sulfidic conditions of deposition.- Earth Planet Sci. Lett., 145, 65-78. doi: 10.1016/S0012$821 \mathrm{X}(96) 00204-\mathrm{X}$

CUCULIĆ, V., CUKROV, N., KWOKAL, Ž. \& MLAKAR, M. (2009): Natural and anthropogenic sources of $\mathrm{Hg}, \mathrm{Cd}, \mathrm{Pb}, \mathrm{Cu}$ and $\mathrm{Zn}$ in seawater and sediment of Mljet National Park, Croatia. Estuar.- Coast. Shelf Sci., 81, 311-320. doi: 10.1016/j.ecss.2008.11.006

CUKROV, N., FRANČIŠKOVIĆ-BILINSKI, S. \& BOGNER, D. (2014): Metal contamination recorded in the sediment of the semi-closed Bakar Bay (Croatia).- Environ. Geochem. Health, 36/2, 195-208. doi: 10.1007/s10653-013-9558-3

ĆOSOVIĆ, V., ZAVODNIK, D., BORČIĆ, A., VIDOVIĆ, J., DEAK, S. \& MORO, A. (2011): A checklist of Foraminifera of the Eastern Shelf of the Adriatic Sea.Zootaxa, 3035, 1-56.

ĆOSOVIĆ, V., GAJSKI, N., PTČIEK, A., VIDOVIĆ, J., \& KRUŽIĆ, P. (2016): The distribution of benthic foraminifera in Cladocora caespitosa coral banks of the Veliko Jezero sediments (Mljet National Park, eastern Adriatic Sea).- Neues Jahrbuch Für Geologie Und Paläontologie - Abhandlungen, 279/3, 323-340. doi: 10.1127/ njgpa/2016/0559

DAVIS, J.C. (1973): Statistics and Data Analysis in Geology.- John Wiley \& Sons, New York, $550 \mathrm{p}$.

DAVIS, J.C. (1986): Statistics and Data Analysis in Geology.-- John Wiley \& Sons, New York, $646 \mathrm{p}$.

DEBENAY, J.P. \& GUILLOU, J.J. (2002): Ecological transitions indicated by foraminiferal assemblages in paralic environments.- Estuaries, 25, 1107-1120. doi: 10.1007/ BF02692208

DEBENAY, J.P. \& GUIRAL, D. (2006): Mangrove swamp foraminifera, indicators of sea level or paleoclimate?- Rev. Paleobiol., 25/2, 567-574.

DEBENAY, J.P. (1990): Recent Foraminiferal Assemblages and their distribution relative to environmental stress in the paralic environments of West Africa (Cape Timiris to Ebrie Lagoon).- J. Foraminifer. Res., 20/3, 267-282. doi: 10.2113/gsjfr.20.3.267

DEBENAY, J.P., GESILIN, E., EICHLER, B.B., DULEBA, W., SYLVESTRE, F. \& EICHLER, P. (2001): Foraminiferal Assemblages in a Hypersaline Lagoon, Araruama (R.J.) Brazil.- J. Foraminifer. Res., 31/2, 133-151. doi: 10.2113/0310133

DELANEY, M.L. (1998): Phosphorus accumulation in marine sediments and the oceanic phosphorus cycle.--Global Biogeochem Cycles, 12/4, 563-572. doi: 10.1029/ 98GB02263
DI, Z., ZHANG, H. \& SHAN, B. (2015): Using sedimentary phosphorus/nitrogen as indicators of shallow lake eutrophication: concentrations or accumulation fluxes.Environ. Earth. Sci., 74/5, 3935-3944. doi: 10.1007/s12665-015-4465-9

DILLON, W.R. \& GOLDSTEIN, M. (1984): Multivariate Analysis: Methods and Applications.- John Wiley \& Sons, New York, $587 \mathrm{p}$.

DIX, G.R., PATTERSON, R.T. \& PARK, L.E. (1999): Marine saline ponds as sedimentary archives of late Holocene climate and sea level variation along a carbonate platform margin: Lee Stocking Island, Bahamas.- Palaeogeogr. Palaeoclimatol. Palaeoecol., 150/3-4, 223-246. doi: 10.1016/S0031-0182(98)00184-9

DONEUS, N., DONEUS, M. \& ETTINGER-STARČIĆ, Z. (2017): The ancient city of Osor, northern Adriatic, in integrated archaeological prospection.- Hortus Artium Mediev., 23/2, 761-775. doi: 10.1484/J.HAM.5.113761

DURN, G., OTTNER, F. \& SLOVENEC, D. (1999): Mineralogical and geochemical indicators of the polygenetic nature of terra rossa in Istria, Croatia.- Geoderma, 91/12, 125-150. doi: 10.1016/S0016-7061(98)00130-X

EDWARDS, R.J., WRIGHT, A.J. \& VAN DE PLASSCHE, O. (2004): Surface distributions of salt-marsh foraminifera from Connecticut, USA: Modern analogues for high-resolution sea level studies.- Mar. Micropaleontol., 51/1-2, 1-21. doi: 10. 1016/j.marmicro.2003.08.002

EMMANOUILIDIS, A., KATRANTSIOTIS, C., NORSTRÖM, E., RISBERG, J., KYLANDER, M., SHEIK, T.A., ILIOPOULOS, G. \& AVRAMIDIS, P. (2018): Middle to late Holocene palaeoenvironmental study of Gialova Lagoon, SW Peloponnese, Greece.- Quat. Int., 476, 46-62. doi: 10.1016/j.quaint.2018.03.005

FAIVRE, S., BAKRAN-PETRICIOLI, T., BAREŠIĆ, J. \& HORVATINČIĆ, N. (2015): New data on marine radiocarbon reservoir effect in the Eastern Adriatic based on pre-bomb marine organisms from the intertidal zone and shallow sea.- Radiocarbon, 57/4, 527-538. doi: 10.2458/azu_rc.57.18452

FELJA, I., FONTANA, A., FURLANI, S., BAJRAKTAREVIĆ, Z., PARADŽIK, A., TOPALOVIĆ, E., ROSSATO, S., ĆOSOVIĆ, V. \& JURAČIĆ, M. (2015): Environmental changes in the lower Mirna river valley (Istria, Croatia) during the middle and late Holocene.- Geol Croat., 68/3, 209-224. doi: 10.4154/GC.2015.16

FOLK, R.L. \& WARD, W.C. (1957): Brazos River bar: a study in the significance of grain size parameters.- Journal of Sedimentary Petrology, 27, 3-26. doi: 10.1306/ 74D70646-2B21-11D7-8648000102C1865D

FORD, D.C. \& WILLIAMS, P. (1989): Karst Geomorphology and Hydrology.- Chapman \& Hall, London, 601 p. doi: 10.1007/978-94-011-7778-8

FRONTALINI, F., ARMNYNOT DU CHÂTELET, E., DEBENAY, J.P., COCCIONI, R. \& BANCALÀ, G. (2011a): Benthic foraminifera in coastal lagoons: distributional patterns and biomonitoring implications.- In: FRIEDMAN, A.G. (eds.): Lagoons: Biology, Management and Environmental Impact. Nova Science Publishers, Inc., 39-72.

FRONTALINI, F., SEMPRUCCI, F., COCCIONI, R., BALSAMO, M., BITTONI, P. \& COVAZZI-HARRIAGUE, A. (2011b): On the quantitative distribution and community structure of the meio and macrofaunal communities in the coastal area of the Central Adriatic Sea (Italy).- Environ. Monit. Assess, 180, 325-344. doi: 10. 1007/s10661-010-1791-y

FRONTALINI, F., MARGARITELLI, G., FRANCESCANGELI, F., RETTORI, R., ARMNYNOT DU CHÂTELET, E., COCCIONI, R. (2013): Benthic foraminiferal assemblages and biotopes in a coastal lake: The case study of Lake Varano (Southern Italy).- Acta Protozool., 52/3, 147-160.

FRONTALINI, F., CURZI, D., GIORDANO, F.M., BERNHARD, J.M., FALCIERI, E. \& COCCIONI, R. (2015): Effects of Lead Pollution on Ammonia Parkinsonia$n a$ (Foraminifera): Ultrastructural and Microanalytical Approaches.- European Journal of Histochemistry, 59/1, 2460. doi: 10.4081/ejh.2015.2460

FUČEK, L., MATIČEC, D., VLAHOVIĆ, I., OŠTRIĆ, N., PRTOLJAN, B., KORBAR, T. \& HUSINEC, A. (2012): Osnovna geološka karta Republike Hrvatske mjerila 1:50 000 - list Cres 2 [Basic Geological Map of Republic of Croatia 1:50 000, Cres 2 Sheet - in Croatian].- Hrvatski geološki institut, Zagreb.

FUČEK, L., MATIČEC, D., VLAHOVIĆ, I., OŠTRIĆ, N., PRTOLJAN, B., KORBAR, T., HUSINEC, A. \& PALENIK, D. (2014): Osnovna geološka karta Republike Hrvatske mjerila 1:50 000 - list Cres 4. [Basic Geological Map of Republic of Croatia 1:50 000, Cres 4 Sheet - in Croatian].- Hrvatski geološki institut, Zagreb.

GAJIĆ-ČAPKA, M., CINDRIĆ, K. \& MIHAJLOVIĆ, D. (2008): Oborina/Precipitation.In: ZANINOVIĆ, K. (eds.): Klimatski atlas Hrvatske / Climate atlas of Croatia 1961-1990., 1971-2000. Državni hidrometeorološki zavod, Zagreb, 34-50.

GALOVIĆ, L. \& PEH, Z. (2016): Mineralogical discrimination of the Pleistocene loess/ paleosol sections in Srijem and Baranja, Croatia.-Aeolian Res., 21, 151-162. doi: 10.1016/j.aeolia.2016.04.006.

GEHRELS, W.R. (1994): Determining Relative Sea-level Change from Salt-marsh Foraminifera and Plant Zones on the Coast of Maine, U.S.A.- J Coast Res., 10/4, 990-1009.

GOLDBERG, S., FORSTER, H.S. \& GODFREY, C.L. (1996): Molybdenum Adsorption on Oxides, Clay Minerals, and Soils.- Soil Sci. Soc. Am. J., 60/2, 425-432. doi: 10.2136/sssaj1996.03615995006000020013x

GOVORČIN, D.P., JURAČIĆ, M., HORVATINČIĆ, N. \& ONOFRI, V. (2001): Holocene sedimentation in the Soline Channel (Mljet Lakes, Adriatic Sea).- Natura Croatica, 10/4, 247-258. 
HAMMER, Ø., HARPER, D.A.T. \& RYAN, P.D. (2001): PAST: Paleontological Statistics Software Package for Education and Data Analysis.- Palaeontologia Electronica 4, 9. http://palaeo-electronica.org/2001_1/past/issue1_01.htm

HAYWARD, B.W., GRENFELL, H.R. \& SCOTT, D.B. (1999): Tidal range of marsh foraminifera for determining former sea level heights in New Zealand.- New Zeal. J. Geol. Geophys., 42/3, 395-413. doi: 10.1080/00288306.1999.9514853

HELALI, M.A., OUESLATI, W., ZAABOUB, N., ADDED, A. \& ABDELJAOUAD, S. (2013): Geochemistry of marine sediments in the mejerda river delta, Tunisia.Chem. Speciat. Bioavailab., 25/4, 247-257. doi: 10.3184/095422913X138400981 60825

HOLTAN, H., KAMP-NIELSEN, L. \& STUANES, A.O. (1988): Phosphorus in soil, water and sediment: an overview.- Hydrobiologia, 170, 19-34. doi: 10.1007/ BF00024896

HUSINEC, A., VELIĆ, I., FUČEK, L., VLAHOVIĆ, I., MATIČEC, D., OŠTRIĆ, N. \& KORBAR, T. (2000): Mid Cretaceous orbitolinid (Foraminiferida) record from the islands of Cres and Losinj (Croatia) and its regional stratigraphic correlation.-Cretac. Res., 21/1, 155-171. doi: 10.1006/cres.2000.0203

ILIJANIĆ, N., MIKO, S., HASAN, O. \& BAKRAČ, K. (2018): Holocene environmental record from lake sediments in the Bokanjačko blato karst polje (Dalmatia, Croatia).- Quat Int. (in press). https://doi.org/10.1016/j.quaint.2018.01.037

JAYALAKSHMY, K.V. \& RAO, K.K. (2006): Aspects of the biodiversity of brackish water foraminifera.- Environ. Forensics., 7/4, 353-367. doi: 10.1080/ 15275920600996370

JORISSEN, F.J. (1988): Benthic Foraminifera from the Adriatic Sea; Principles of phenotypic variation.- Utrecht Micropaleontological Bulletins, 37, $174 \mathrm{p}$.

JURAČIĆ, M., SONDI, I., BARIŠIĆ, D. \& PRAVDIĆ, V. (1995): Sedimenti i sedimentacija u Mljetskim Jezerima (Hrvatska). Prirodne značajke i društvena valorizacija otoka Mljeta.- In: DURBEŠIĆ, P. \& BENOVIĆ, A. (eds.): Ekološke monografije 6. Hrvatsko ekološko društvo, Pomena, otok Mljet, 107-116.

JURAČIĆ, M., BENAC, Č., \& CRMARIĆ, R. (1999): Seabed and surface sediment map of the Kvarner region, Adriatic Sea, Croatia (Lithological map, M 1:500,000).Geol. Croat., 52, 131-140.

KELLETAT, D.H. (2005): Dalmatian Coasts.- In: SCHWARTZ, M.L. (eds.): Encyclopedia of Coastal Science.- Encyclopedia of Earth Sciences Series. Dordrecht, The Netherlands, Springer, 456-462. doi: 10.1007/1-4020-3880-1_107

KEMP, A.C., TELFORD, R.J., HORTON, B.P., ANISFELD, S.C. \& SOMMERFIELD, C.K. (2013): Reconstructing Holocene sea level using salt-marsh foraminifera and transfer functions: Lessons from New Jersey, USA.- J. Quat. Sci., 28/6, 617-629. doi: 10.1002 jqs. 2657

KOMAR, D., DOLENEC, M., LAMBAŠA BELAK, Ž., MATEŠIĆ, S.S., LOJEN, S., KNIEWALD, G., VRHOVNIK, P., DOLENEC, T. \& ROGAN ŠMUC, N. (2015): Geochemical characterization and environmental status of Makirina Bay sediments (northern Dalmatia, Republic of Croatia).- Geol. Croat., 68/1, 79-92. doi: 10.4154/ GC.2015.06

KORBAR, T. \& HUSINEC, A. (2003): Biostratigraphy of Turonian to (?) Coniacian Platform Carbonates: A Case Study from the Cres Island (Northern Adriatic, Croatia).Geol. Croat., 56/2, 173-185.

KORBAR, T., FUČEK, L., HUSINEC, A., VLAHOVIĆ, I., OŠTRIĆ, N., MATIČEC, D. \& JELASKA, V. (2001): Cenomanian carbonate facies and rudists along shallow intraplatform basin margin-the island of Cres (Adriatic Sea, Croatia).- Facies, 45, 39-58. doi: 10.1007/BF02668104

LAMB, A.L., WILSON, G.P. \& LENG, M.J. (2006): A review of coastal palaeoclimate and relative sea level reconstructions using $\delta 13 \mathrm{C}$ and $\mathrm{C} / \mathrm{N}$ ratios in organic material.- Earth-Science Rev., 75/1-4, 29-57.

LAMBECK, K., ROUBY, H., PURCELL, A., SUN, Y. \& SAMBRIDGE, M. (2014): Sea level and global ice volumes from the Last Glacial Maximum to the Holocene.Proc. Natl. Acad. Sci., 111/43, 15296-15303. doi: 10.1073/pnas.1411762111

LIDZ, B.H. \& ROSE, P. (1989): Diagnostic Foraminiferal Assemblages of Florida Bay and adjacent shallow waters: A comparison.- Bulletin of Marine Science, 44/1, 399-418.

LOEBLICH, JR., A.R. \& TAPPAN, H. (1987): Foraminiferal Genera and their Classification.- Van Nostrand Reinhold, New York, 970 p. doi: 10.1007/978-1-4899-5760-3

LORING, D.H. (1978): Geochemistry of zinc, copper and lead in the sediments of the estuary and Gulf of St Lawrence.- Can. J. Earth. Sci., 15, 757-772. doi: 10.1139/ e78-082

LOVELL, D., PAWLOWSKY-GLAHN, V., EGOZCUE, J.J., MARGUERAT, S. \& BÄHLER, J. (2015): Proportionality: a valid alternative to correlation for relative data.- PLoS Comput. Biol., 11/3, 1-12. Doi: 10.1371/journal.pcbi.1004075.

MACKENZIE, F.T., VINK, S., WOLLAST, R. \& CHOU, L. (1995): Comparative geochemistry of marine saline lakes.- In: LERMAN, A., IMBODEN, D.M. \& GAT, J.R. (eds.): Physics and chemistry of Lakes. Springer Verlag, Berlin, 265-278. doi: 10.1007/978-3-642-85132-2 9

MAGAŠ, N. (1968): Osnovna geološka karta SFRJ, list Cres, 1:100 000, L33-113 [Basic Geological Map of SFRJ: Cres Sheet L33-113 - in Croatian].- Institut za geološka istraživanja, Zagreb. Savezni geološki zavod, Beograd.
MAKLED, W.A. \& LANGER, M.R. (2010): Preferential selection of titanium-bearing minerals in agglutinated Foraminifera: Ilmenite $\left(\mathrm{FeTiO}_{3}\right)$ in Textularia hauerii d'Orbigny from the Bazaruto Archipelago, Mozambique.- Rev. Micropaleontol., 53, 163-173. doi: 10.1016/j.revmic.2009.11.001

MAMUŽIĆ, P. (1968): Osnovna geološka karta SFRJ, list Lošinj, 1:100 000, L33-125 [Basic Geological Map of SFRJ: Cres Sheet L33-125 - in Croatian].- Institut za geološka istraživanja, Zagreb. Savezni geološki zavod, Beograd.

MARRINER, N., MORHANGE, C., FAIVRE, S., FLAUX, C., VACCHI, M., MIKO, S., DUMAS, V., BOETTO, G. \& RADIC ROSSI, I. (2014): Post-Roman sea level changes on Pag Island (Adriatic Sea): Dating Croatia's "enigmatic" coastal notch?Geomorphology, 221, 83-94. doi: 10.1016/j.geomorph.2014.06.002

MATEO, R. (2009): Lead poisoning in wild birds in Europe and the regulations adopted by different countries.- In: WATSON, R.T., FULLER, M., POKRAS, M. \& HUNT, W.G. (eds.): Ingestion of Lead from Spent Ammunition: Implications for Wildlife and Humans. The Peregrine Fund, Boise, Idaho, USA. doi: 10.4080/ilsa.2009.0107

MAYAYO, M.J., TORRES-RUIZ, J., GONZALEZ-LOPEZ, J.M., LOPEZ-GALINDO, A. \& BAULUZ, B. (1998): Mineralogical and chemical characterization of the sepiolite Mg-smectite deposit at Mara (Calatayud Basin, Spain).- Eur. J. Mineral., 10/2, 367-383. doi: 10.1127/ejm/10/2/0367

MEUNIER, A. (2003): Clays.- Springer Verlag, Berlin, Heidelberg, 476 p.

MEYERS, P.A. (1994): Preservation of elemental and isotopic source identification of sediemntary organic matter-- Chem. Geol., 114, 289-302.

MEYERS, P.A. (2003): Application of organic geochemistry to paleolimnological reconstruction: a summary of examples from the Laurention Great Lakes.- Org. Geochem., 34, 261-289. doi: 10.1016/S0146-6380(02)00168-7

MIGANI, F., BORGHESI, F. \& DINELLI, E. (2015): Geochemical characterization of surface sediments from the northern Adriatic wetlands around the Po river delta. Part I: Bulk composition and relation to local background.- Journal of Geochemical Exploration, 156, 72-88.

MIHELČIĆ, G., ŠURIJA, B., JURAČIĆ, M., BARIŠIĆ, D. \& BRANICA, M. (1996): History of the accumulation of trace metals in sediments of the saline Rogoznica Lake (Croatia).- Sci. Total Environ., 182/1-3, 105-15.

MIKO, S., HALAMIĆ, J., PEH, Z. \& GALOVIĆ, L. (2001): Geochemical Baseline Mapping of Soils Developed on Diverse Bedrock from Two Regions in Croatia.- Geol. Croat., 54/1, 53-118.

MIKO, S., KOCH, G., MESIČ, S., ŠPARICA-MIKO, M., ŠPARICA, M., ČEPELAK, R., BAČANI, A., VREČA, P., DOLENEC, T. \& BERGANT, S. (2008): Anthropogenic influence on trace element geochemistry of healing mud (peloid) from Makirina Cove (Croatia).- Environ. Geol., 55, 517-537. doi: 10.1007/s00254-0070997-y

MIKO, S., KOCH, G., MESIĆ, S., ŠPARICA-MIKO, M., ŠPARICA, M., VREČA, P. \& DOLENEC, T. (2007): Influence of land use in small karst watersheds on the chemical status of peloid sediments on the eastern Adriatic coast.- J. Soils Sediments, 7/5, 303-312. doi: 10.1065/jss2007.10.25

MILKER, Y., HORTON, B.P., NELSON, A.R., ENGELHART, S.E. \& WITTER, R.C. (2015): Variability of intertidal foraminiferal assemblages in a salt marsh, Oregon, USA.- Mar Micropaleontol, 118, 1-16. doi: 10.1016/j.marmicro.2015.04.004

MLAKAR, M., FIKET, Ž., GEČEK, S., CUKROV, N. \& CUCULIĆ, V. (2015): Marine lake as in situ laboratory for studies of organic matter influence on speciation and distribution of trace metals.- Shelf Research, 103, 1-11. doi: 10.1016/j.csr.2015. 04.024

MOCOCHAIN, L., AUDRA, P., CLAUZON, G., BELLIER, O., BIGOT, J.Y., PARIZE, O. \& MONTEIL, P. (2009): The effect of river dynamics induced by the Messinian Salinity Crisis on karst landscape and caves: Example of the Lower Ardèche river (mid Rhône valley).- Geomorphology, 106/1-2, 46-61. doi: 10.1016/j.geomorph. 2008.09.021

MOORE, D.M. \& REYNOLDS, R.C. (1997): X-ray diffraction and the identification and analysis of clay minerals.- Second edition. Oxford Univ. Press, Oxford, 378 p.

MÜLLER-NAVARA, K., MILKER, Y. \& SCHMIEDL, G. (2017): Applicability of transfer functions for relative sea level reconstructions in the southern North Sea coastal region based on salt-marsh foraminifera.- Marine Micropaleontology, 135, 1531. doi: 10.1016/j.marmicro.2017.06.003

MURRAY, J.W. (2006): Ecology and Applications of Benthic Foraminifera.- Cambridge University Press, Cambridge, New York, 426 p. doi: 10.1017/CBO9780511535529

ORDÓÑEZ, S., CALVO, J.P., GARCÍA-DEL-CURA, M.A., ALONSO-ZARZA, A.M. \& HOYOS, M. (1991): Sedimentology of Sodium Sulphate Deposits and Special Clays from the Tertiary Madrid Basin (Spain).- Spec. Publs Int. Ass. Sediment., 13, 39-55. doi: 10.1002/9781444303919.ch2

PANDŽA, M., FRANJIĆ, J. \& ŠKVORC, Ž. (2007): The salt marsh vegetation on the East Adriatic coast.- Biologia, 62, 24-31. doi: 10.2478/s11756-007-0003-X

PANDŽIĆ, K. \& LIKSO, T. (2005): Eastern Adriatic typical wind field patterns and largescale atmospheric conditions.- Int. J. Climatol., 25, 81-98. doi: 10.1002/joc.1085

PEDERSEN, T.F., WATERS, R.D. \& MACDONALD, R.W. (1989): On the natural enrichment of cadmium and molybdenum in the sediments of ucluelet inlet, British Columbia.-Sci. Total Environ., 79/2, 125-139. doi: 10.1016/0048-9697(89)90357-4 
PEH, Z. \& KOVAČEVIĆ GALOVIĆ, E. (2014): Geochemistry of Istrian Lower Palaeogene bauxites - is it relevant to the extent of subaerial exposure during Cretaceous times?- Ore Geol. Rev., 63, 296-306. doi: 10.1016/j.oregeorev.2014.05.020

PEH, Z. \& KOVAČEVIĆ GALOVIĆ, E. (2016): Geochemistry of Lower Palaeogene bauxites - a unique signature for the tectonostratigraphic evolution of part of the Croatian Karst.- Geol. Croat., 69/2, 269-279. doi: 10.4154/gc.2016.24

PIKELJ, K., ŽIGIĆ, V. \& JURAČIĆ, M. (2009): Origin and distribution of surface sediments in the Grgur Channel, Adriatic Sea, Croatia.- Geol. Croat., 62, 95-105. doi: $10.4154 / \mathrm{gc} .2009 .08$

PIKELJ, K. (2010): Sastav i porijeklo sedimenata dna istočne strane Jadranskog mora.Unpubl. PhD Thesis, Faculty of Science, University of Zagreb, 247 p.

PIKELJ, K. \& JURAČIĆ, M. (2013): Eastern Adriatic Coast (EAC): Geomorphology and Coastal Vulnerability of a Karstic Coast.- J. Coast. Res., 289, 944-957. doi: 10. 2112/JCOASTRES-D-12-00136.1

POPADIĆ, A., VIDOVIĆ, J., ĆOSOVIĆ, V., MEDAKOVIĆ, D., DOLENEC, M. \& FELJA, I. (2013): Impact evaluation of the industrial activities in the Bay of Bakar (Adriatic Sea, Croatia): Recent benthic foraminifera and heavy metals.- Mar. Pollut. Bull., 76/1-2, 333-248. doi: 10.1016/j.marpolbul.2013.09.039

REGAN, K \& NADILO, B. (2010): Crkveno graditeljstvo, stare crkve na Cresu i Lošinju te okolnim otocima.- Građevinar, 62/2, 151-161.

REIMANN, C., FILZMOSER, P., GARRETT, R.G. \& DUTTER, R. (2008): Statistical Data Analysis Explained: Applied Environmental Statistics With R.- John Wiley \& Sons, Ltd., 343 p. doi: 10.1002/9780470987605

ROCK, N.M.S. (1988): Lecture Notes in Earth Sciences, 18: Numerical Geology.- Springer Verlag, Berlin, $427 \mathrm{p}$

ROMANO, M., FERREYRA, H., FERREYROA, G., MOLINA, F. V., CASELLI, A. BARBERIS, I., BELDOMÉNICO, P. \& UHART, M. (2016): Lead pollution from waterfowl hunting in wetlands and rice fields in Argentina.- Sci. Total. Environ., 545-546, 104-13. doi: 10.1016/j.scitotenv.2015.12.075

SCHMIDT, R., MÜLLER, J., DRSCHER-SCHNEIDER, R., KRISAI, R., SZEROCZYNSKA, K. \& BARIĆ, A. (2000): Changes in lake level and trophy at Lake Vrana, a large karstic lake on the Cres Island (Croatia).- J. Limnol., 59/2, 113-130.

SCHMIDT, R., PUGLIESE, N., MÜLLER, J., SZEROCZYŃSKA, K., BOGNER, D., MELIS, R., KAMENIK, C., BARIČ, A. \& DANIELOPOL, D.L. (2001): Palaeoclimate, vegetation and coastal lake development, from Upper Pleniglacial until early Holocene, in the Northern Adriatic Valun Bay (Isle of Cres, Croatia).- Il Quaternario, 14/1, 61-78

SCHOLZ, F., SIEBERT, C., DALE, A.W. \& FRANK, M. (2017): Intense molybdenum accumulation in sediments underneath a nitrogenous water column and implications for the reconstruction of paleo-redox conditions based on molybdenum isotopes.-Geochim. Cosmochim. Acta, 213, 400-417. doi: 10.1016/j.gca.2017.06.048

SCHÖNFELD, J., ALVE, E., GESLIN, E., JORISSEN, F., KORSUN, S., SPEZZAFERRI, S. \& MEMBERS OF THE FOBIMO GROUP (2012): The FOBIMO (FOraminiferal BIo-MOnitoring) initiative-Towards a standardised protocol for softbottom benthic foraminiferal monitoring studies.- Marine Micropaleontology, 94-95, 1-13.

SEN GUPTA, B.K., SMITH, L.E. \& MACHAIN-CASTILLO, M.L. (2009): Foraminifera of the Gulf of Mexico.- In: FELDER, D.L. \& CAMP, D.K. (eds.): Gulf of Mexico-Origins, Waters, and Biota. Texas A\&M University Press, College Station, Texas, $87-129$

SEN GUPTA, B.K. (1999): Foraminifera in marginal marine environments.- In: SEN GUPTA, B.K. (eds.): Modern Foraminifera. Kluwer Academic Publishers, Dordrecht, Boston, 141-159. doi: 10.1007/0-306-48104-9_9

SERANDREI BARBERO, R., CARBOGNIN, L., TARONI, G. \& COVA, E. (1999): Distribution of recent benthic foraminifera in the southern basin of the Venice lagoon (Italy): Statistical evaluation of taxa significance.- Micropaleontology, 45/1, 99-111. doi: $10.2307 / 1486205$

SERANDREI BARBERO, R., ALBANI, A.D. \& BONARDI, M. (2004): Ancient and modern salt marshes in the Lagoon of Venice.- Palaeogeogr. Palaeoclimatol. Palaeoecol., 202/3-4, 229-244. doi: 10.1016/S0031-0182(03)00636-9

SGARRELLA, F. \& MONCHARMONT ZEI, M. (1993): Benthic Foraminifera of the Gulf of Naples (Italy): systematics and autoecology.- Bollettino della Societá Paleontologica Italiana, 32/2, 145-264.

SHAW, T.A., KIRBY, J.R., HOLGATE, S., TUTMAN, P. \& PLATER, A.J. (2016): Contemporary salt-marsh foraminiferal distribution from the Adriatic coast of Croatia and its potential for sea level studies.- J Foraminifer Res, 46/3, 314-332. doi: $10.2113 /$ gsjfr.46.3.314

SIGNELL, R.P., CHIGGIATO, J., HORSTMANN, J., DOYLE, J.D., PULLEN, J. \& ASKARI, F. (2010): High-resolution mapping of Bora winds in the northern Adriatic Sea using synthetic aperture radar-- J. Geophys. Res. Ocean., 115, 1-20. doi: 10.1029/2009JC005524

SONDI, I. \& JURAČIĆ, M. (2010): Whiting events and the formation of aragonite in Mediterranean karstic marine lakes: New evidence on its biologically induced inorganic origin.-Sedimentology, 57/1,85-95. doi: 10.1111/j.1365-3091.2009.01090.x

SONDI, I., MIKAC, N., VDOVIĆ, N., IVANIĆ, M., FURDEK, M. \& ŠKAPIN, S.D. (2017): Geochemistry of recent aragonite-rich sediments in Mediterranean karstic marine lakes: Trace elements as pollution and palaeoredox proxies and indicators of authigenic mineral formation.- Chemosphere, 168, 786-797. doi: 10.1016/j.chemosphere.2016.10.134

STARKEY, H.C. \& BLACKMON, P.D. (1984): Sepiolite in Pleistocene Lake Tecopa, Inyo County, California.- Developments in Sedimentology, 37, 137-147.

STÉPHAN, P., GOSLIN, J., PAILLER, Y., MANCEAU, R., SUANEZ, S., VAN VLIETLANOË, B., HÉNAFF, A. \& DELACOURT, C. (2015): Holocene salt-marsh sedimentary infilling and relative sea level changes in West Brittany (France) using foraminifera-based transfer functions.- Boreas, 44/1, 153-177. doi: 10.1111/bor. 12092

SUOKHRIE, T., SARASWAT, R. \& NIGAM, R. (2017): Foraminifera as Bio-Indicators of Pollution: A Review of Research over the Last Decade.- In: KATHAL, P.K., NIGAM, R. \& TALIB, A. (eds.): Micropaleontology and its Applications.-Scientific Publishers (India), 265-284.

SURIĆ, M. (2002): Submarine Karst of Croatia - Evidence of Former Lower Sea Levels Podmorski Kras Na Hrvaškem - Dokaz o nekdanji nižji morski gladini.-Acta Carsologica, 31/3, 89-98.

SURIĆ, M. (2005): Submerged karst - dead or alive? Examples from the Eastern Adriatic Coast (Croatia).- Geoadria, 10/1, 5-19.

STATSOFT, Inc. (2011). STATISTICA (data analysis software system), version 10. www. statsoft.com.

ŠEGOTA, T. \& FILIPČIĆ, A. (2003): Köppenova podjela klima i hrvatsko nazivlje.Geoadria, 8/1, 17-37.

ŠORŠA, A., PEH, Z. \& HALAMIĆ, J. (2018): Geochemical mapping the urban and industrial legacy of Sisak, Croatia, using discriminant function analysis of topsoil chemical data.- J. Geochem. Explor., 187, 155-167. doi: 10.1016/j.gexplo.2017. 07.014

ŠPARICA, M., KOCH, G., BELAK, M., MIKO, S., ŠPARICA MIKO, M., VILIČIĆ, D., DOLENEC, T., BERGANT, S., LOJEN, S., VREČA, P., DOLENEC, M., OGRINC, N. \& IBRAHIMPAŠIĆ, H. (2005): Recent sediments of Makirina bay (northern Dalmatia, Croatia): their origin viewed through a multidisciplinary approach.- Geol. Croat., 58/1, 21-71.

TAHER, A.G. (2001): Geochemistry of recent marine sediments in the Bardawil lagoon, northern Sinai, Egypt.- Hydrobiologia, 457, 5-16.

TAKATA, H. (2006): Foraminifera in an Organic-Rich, Brackish-Water Lagoon, Lake Saroma, Hokkaido, Japan.- J. Foraminifer. Res., 36/1, 44-60. doi: 10.2113/36.1.44

TUNG, J.W.T. \& TANNER, P.A. (2003): Instrumental determination of organic carbon in marine sediments.- Marine Chemistry, 80, 161-170. doi: 10.1016/S0304-4203 (02)00116-0

VANIČEK, V., JURAČIĆ, M., BAJRAKTEREVIĆ, Z. \& ĆOSOVIĆ, V. (2000): Benthic foraminiferal assemblages in a restricted environment-an example from the Mljet Lakes (Adriatic Sea, Croatia).- Geol Croat., 53/2, 269-280.

VACCHI, M., MARRINER, N., MORHANGE, C., SPADA, G., FONTANA, A. \& ROVERE, A. (2016): Multiproxy assessment of Holocene relative sea level changes in the western Mediterranean: Sea-level variability and improvements in the definition of the isostatic signal.- Earth-Science Rev., 155, 172-197. doi: 10.1016/j. earscirev.2016.02.002

VELDE, B. (1995): Composition and Mineralogy of Clay Minerals.- In: VELDE, B. (eds.): Origin and Mineralogy of Clays. Springer Verlag, Berlin, Heidelberg, New York, 8-42.

VIDOVIĆ, J. (2010): Analiza utjecaja prirodnih promjena i antropogenog djelovanja na zajednice foraminifera u sedimentima istočne obale Jadranskog mora.- Unpubl. PhD Thesis, Faculty of Science, University of Zagreb, 218 p.

VIDOVIĆ, J., ĆOSOVIĆ, V., JURAČIĆ, M. \& PETRICIOLI, D. (2009): Impact of fish farming on foraminiferal community, Drvenik Veliki Island, Adriatic Sea, Croatia.Mar Pollut Bull., 58/9, 1297-1309. doi: 10.1016/j.marpolbul.2009.04.031

VIDOVIĆ, J., DOLENEC, M., DOLENEC, T., KARAMARKO, V. \& ŽVAB ROŽIČ, P. (2014): Benthic foraminifera assemblages as elemental pollution bioindicator in marine sediments around fish farm (Vrgada Island, Central Adriatic, Croatia).- Mar Pollut Bull., 83/1, 198-213. doi: 10.1016/j.marpolbul.2014.03.051

WAELBROEK, C., LABEYRIE, L., MICHEL, E., DUPLESSY, J.C., MCMANUS, J.F., LAMBECK, K., BALBON, E. \& LABRACHERIE, M. (2002): Sea level and deep water temperature changes derived from benthic foraminifera isotopic records.Quaternary Science Reviews, 21, 295-305. doi: 10.1016/S0277-3791(01)00101-9

WUNSAM, S., SCHMIDT, R. \& MULLER, J. (1999): Holocene lake development on two Dalmatian lagoons (Malo and Veliko Jezero, Isle of Mljet) in respect to changes in Adriatic sea level and climate.- Palaeogeography, Palaeoclimatology, Palaeoecology, 146, 251-281. doi: 10.1016/S0031-0182(98)00147-3

ZANINOVIĆ, K., GAJIĆ-ČAPKA, M., PERČEC TADIĆ, M., VUČETIĆ, M., MILKOVIĆ, J., BAJIĆ, A., CINDRIĆ, K., CVITAN, L., KATUŠIN, Z., KAUČIĆ, D., LIKSO, T., LONČAR, E., LONČAR, Ž., MIHAJLOVIĆ, D., PANDŽIĆ, K., PATARČIĆ, M., SRNEC, L. \& VUČETIĆ, V. (2008): Klimatski atlas Hrvatske / Climate atlas of Croatia 1961-1990., 1971-2000.- Državni hidrometeorološki zavod, Zagreb, $200 \mathrm{p}$. 
1

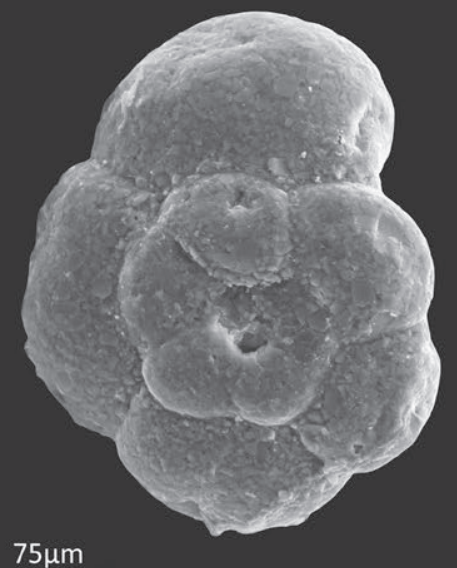

4

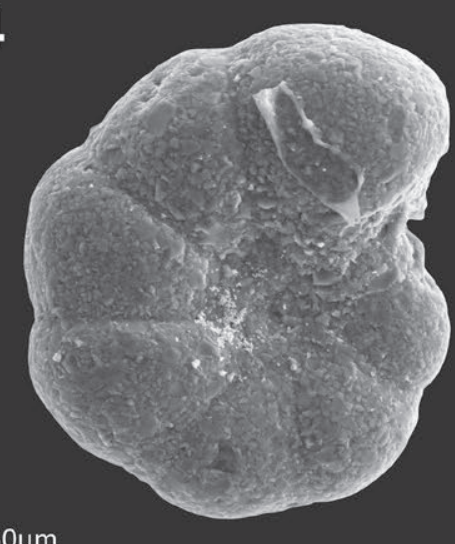

$50 \mu \mathrm{m}$

7

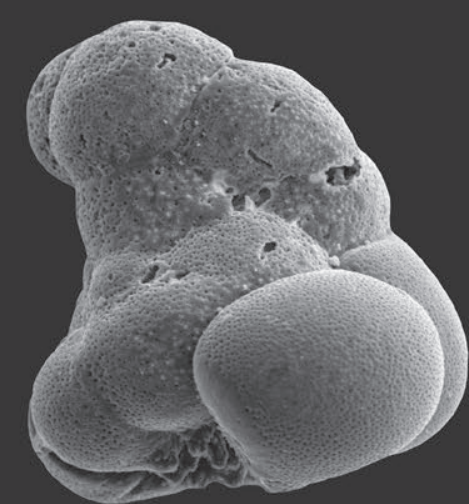

$125 \mu \mathrm{m}$
2

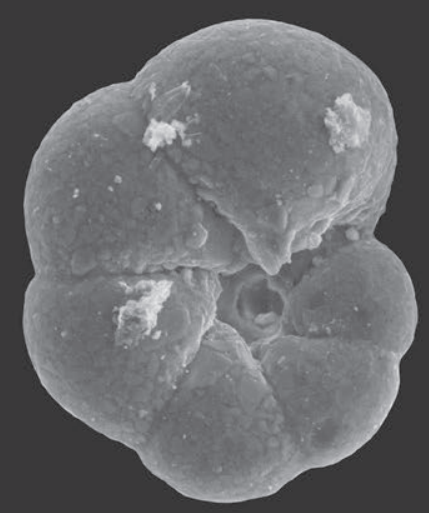

$25 \mu \mathrm{m}$

5

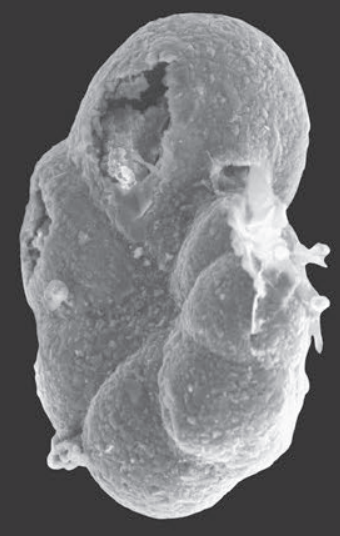

$50 \mu \mathrm{m}$

8

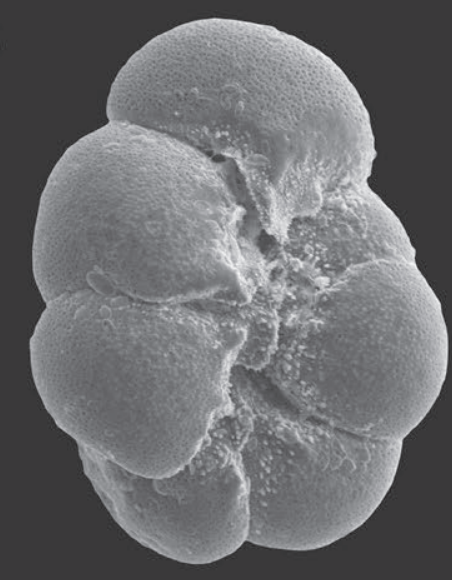

$100 \mu \mathrm{m}$

\section{PLATE I}

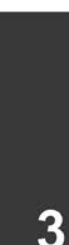

3

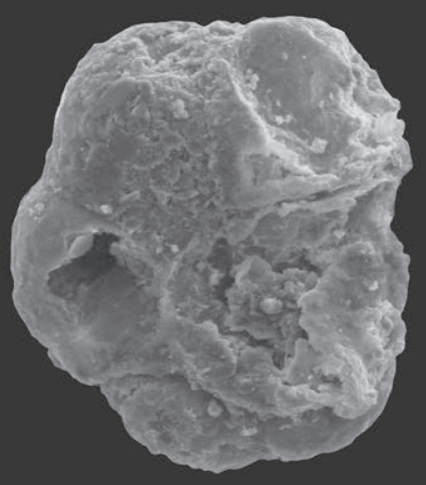

$75 \mu \mathrm{m}$

6

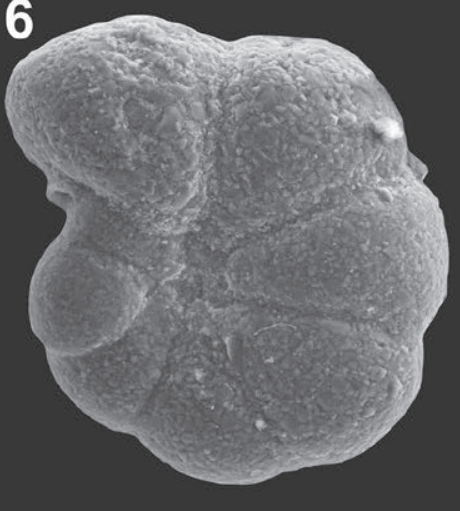

$50 \mu \mathrm{m}$

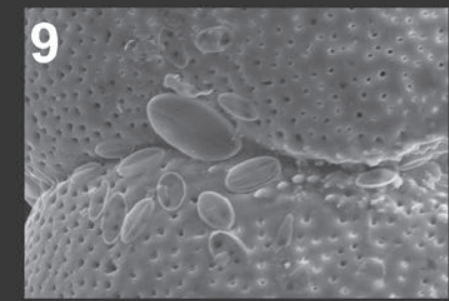

$25 \mu \mathrm{m}$

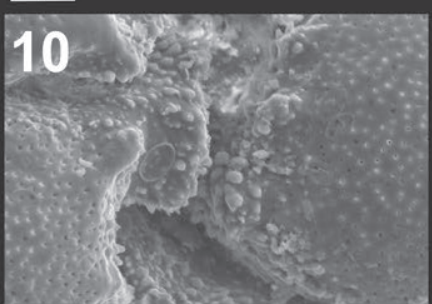

$50 \mu \mathrm{m}$

Plate 1.

Foraminifera specimens from marine ponds: 1-3 Trochammina inflata (MONTAGU), 1 spiral side, 2 umbilical side, 3 spiral side with deflated chambers; 4-6 Haplophragmoides canariensis (d'ORBIGNY), 4 side view, 5 face view, 6 side view; 7 side view; 7-11 Ammonia tepida (CUSHMAN), 7 deformed specimen, 8 umbilical view, 9 enlargement of the test surface with diatoms, 10 enlargement of the test surface. 


\section{PLATE II}

1

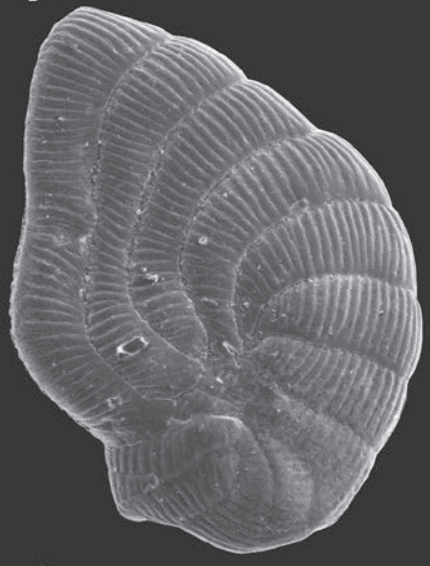

$125 \mu \mathrm{m}$

4

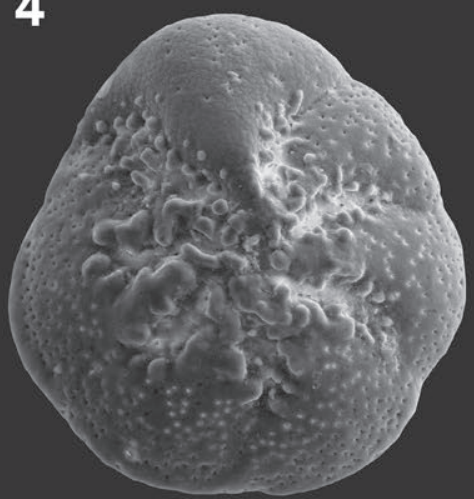

$50 \mu \mathrm{m}$

7

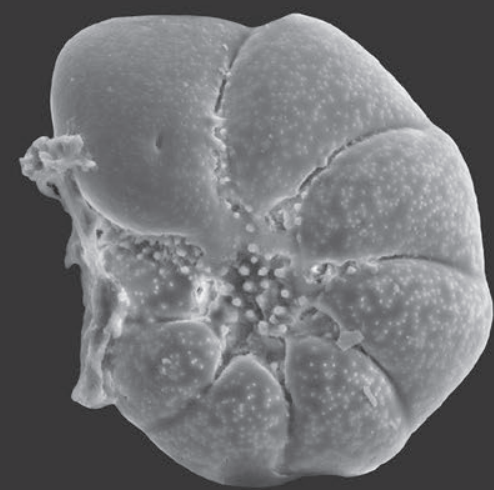

$25 \mu \mathrm{m}$
2

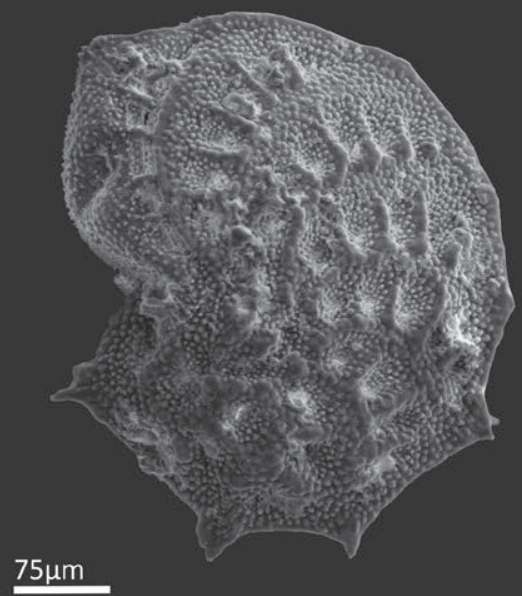

5

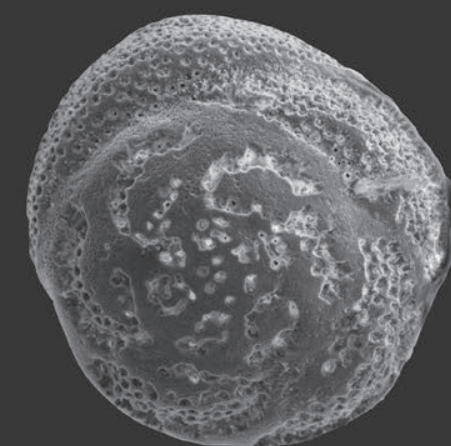

$100 \mu \mathrm{m}$

8

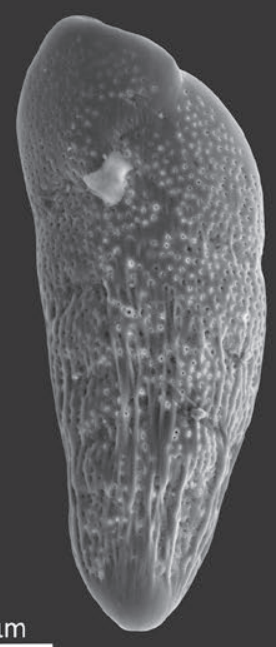

3

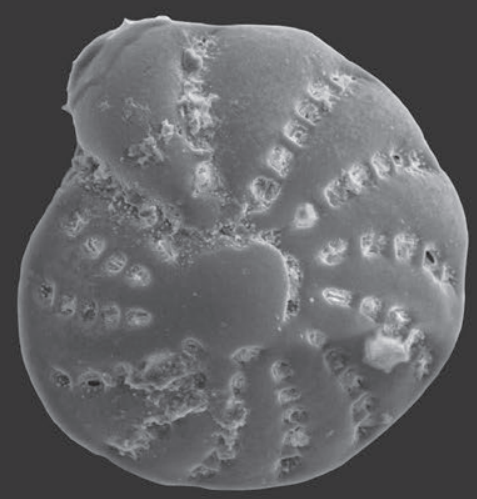

$75 \mu \mathrm{m}$

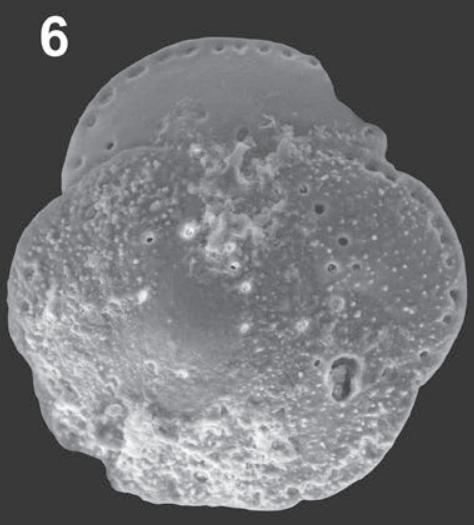

$25 \mu \mathrm{m}$

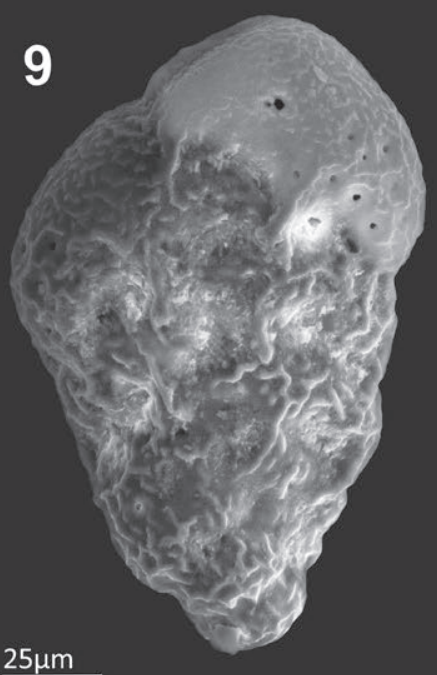

Plate 2.

Foraminifera specimens from the Jaz and Sonte embayments: 1 Peneroplis planatus (FICHTEL \& MOLL) side view; 2 Elphidium aculeatum (d'ORBIGNY) side view; 3 Cribroelphidium gerthi (van VOORTHUYSEN) side view; 4 Buccella sp.2 umbilical side; 5 Rosalina macropora (HOFKER) spiral side; Asterigerinata mamilla (WILLIAMSON) spiral side; 7 Haynesina depressula (WALKER \& JACOB) side view; 8 Bolivina striatula (CUSHMAN) side view; 9 Bolivina pseudoplicata (HERON-ALLEN \& EARLAND) side view. 